\title{
Etkileşim Temelli Erken Çocuklukta Müdahale Programı'nın (ETEÇOM) Otizm Spektrum Bozukluğu sergileyen çocukların sosyal etkileşim becerileri üzerindeki etkililiğii*
}

\author{
The Efficacy of Responsive Teaching (RT) Program on social interaction \\ skills of children with Autism Spectrum Disorder**
}

\author{
Ömür Gürel Selimoğlu ${ }^{1}$, Selda Özdemir ${ }^{2}$
}

\begin{abstract}
Makale Geçmişi
Geliş : :19 Temmuz 2018

Düzeltme : 20 Ağustos 2018

Kabul : 03 Eylül 2018

Çevrimiçi : 06 Eylül 2018
\end{abstract}

Makale Türü

Özgün Makale

\author{
Article History \\ Received : 19 July 2018 \\ Revised : 20 August 2018 \\ Accepted : 03 September 2018 \\ Online : 06 September 2018 \\ Article Type \\ Original Article
}

\begin{abstract}
Öz: Bu araştırmada, Etkileşim Temelli Erken Çocuklukta Müdahale Programı'nı (ETEÇOM), otizm spektrum bozukluğu (OSB) sergileyen çocukların sosyal etkileşim becerileri üzerine etkililiği araştırılmıştır. Araştırma, üç OSB'li çocuk ve anneleri ile gerçekleştirilmiştir. Katılımcı çocukların ikisi erkek biri kızdır. Birinci katılımcı çocuğun yaşı, çalışmaya başlandığı tarih itibariyle 6, ikinci katılımcı çocuk 4, üçüncü katılımcı çocuk 3 yas 2 aylıktır. Katılımcı annelerin yaşları 33-35 yas arasıdır. Bu araștırmanın uygulamaları, Ankara'da bir devlet üniversitesinin özel gereksinimli çocuklar için açılmış araştırma ve uygulama merkezi ile bir katılımcı çocuğun devam ettiği kurumda (özel özel eğitim ve rehabilitasyon merkezi) gerçekleştirilmiştir. Araştırmanın izleme oturumları ise katılımcıların evlerinde doğal ortamlarında gerçekleşmiştir. Araştırmada, ETEÇOM Programı'nın çocuk katılımcıların sosyal etkileşim becerilerine etkisi tek denekli deneysel desenlerden denekler arası çoklu başlama düzeyi desenine yer verilerek uygulama öncesi, sırası ve sonrası gözlem verileri yoluyla toplanmıştır. Araştırmanın uygulamaları 4 aşamada tamamlanmıştır. $\mathrm{Bu}$ aşamalar, katılımcıların başlama düzeylerinin belirlenmesi, ETEÇOM Programı'ın uygulanması, ETEÇOM Programı sonu değerlendirme ve izlemedir. Araştırma sonunda, çocukların sosyal etkileşim becerilerinde (etkileşimi başlatma, etkileşime yanıt verme ve etkileşimi sürdürme sayı ve yüzdesi) ilerlemeler gösterdikleri belirlenmiştir.
\end{abstract}

Anahtar Kelimeler: Sosyal etkileşim becerileri; Ebeveyn-çocuk etkileşimi; ETEÇOM Programı; Otizm spektrum bozukluğu

\begin{abstract}
In this study, the effectiveness of the Interaction-Based Early Childhood Intervention Program called Responsive Teaching (RT) on the social interaction skills of children with autism spectrum disorder (ASD) was investigated. The study was conducted with three children with ASD and their mothers. In terms of the gender of the participant children, one of them is girl, while the other two are boys. The age of the first participant child is 6 as of the starting date of the study, the second participant child is 4 years old, and the third participant child is 3 years and 2 months old. The ages of the participant mothers are between 33 and 35 years. The applications of this study were performed at the research and application centre opened for children with special needs at a state university in Ankara and in an institution which a participant child attends (private special education and rehabilitation centre). The follow-up sessions of the study were held in the houses of the participants, in their natural environment. In the study, the effect of the RT on the social interaction skills of the child participants was collected using the pre-application, during application and post-application observation data by incorporating the inter-subject multiple baseline design among single subject experimental patterns. The applications of the study were completed in 4 stages. These stages consist of determining the starting levels of the participants, the implementation of the RT, post RT assessment and follow-up. As a result of the study, advancements were determined in the social interaction skills of the children.
\end{abstract}

Keywords: Social engagement skills; Parent-child interactions; Responsive teaching; Autism spectrum disorder

\footnotetext{
* Bu araştırma Ömür Gürel Selimoğlu tarafından Selda Özdemir danışmanlığında hazırlanan doktora tezinin bir bölümüdür.

** Bu araştırma, 7th International Conference of Strategic Research on Social Science and Education 2017, 13-15 October, Antalya/Turkey 'de sözlü bildiri olarak sunulmuştur.

1'Akdeniz Üniversitesi, Eğitim Fakültesi, Özel Eğitim Bölümü, oselimoglu @akdeniz.edu.tr, ORCID: https://orcid.org/0000-0003-3212-713X

${ }^{2}$ Gazi Üniversitesi, Eğitim Fakülte, Özel Eğitim Bölümü, seldaozdemir@ gazi.edu.tr, ORCID: http://orcid.org/0000-0002-3925-2702
}

Atıf için/To cite this article:

Gürel Selimoğlu, Ö., \& Özdemir, S. (2018). Etkileşim Temelli Erken Çocuklukta Müdahale Programi'nın (ETEÇOM) Otizm Spektrum Bozukluğu sergileyen çocukların sosyal etkileşim becerileri üzerindeki etkililiği. Erken Cocukluk Calsşmalar Dergisi, 2(3), 514-555. doi:http://dx.doi.org/10.24130/eccd-jecs.196720182399 


\section{SUMMARY}

\section{Introduction}

Children exhibiting normal development use a wide range of social interaction (such as mimics, gestures, speech, social association and face expressions, etc.) while interacting with their families and peers (Charlop, Dennis, Carpenter and Greenberg, 2010). Contrary to this situation, children with ASD exhibit significant problems in using their social interaction skills (Charlop et al., 2010). Children with ASD are less willing to interact with other people. They prefer playing alone more, their skills of making friends and being preferred as playmates are more limited, and their quality to interact is at a low level (Baker et al., 2007; Charlop et al., 2010; Cotugno, 2009; McConnell, 2002).

While the limitations in social interaction are among the early indicators of ASD, suitable interventions that will improve the possible effects of the limitations in social skills and retarded social development generally tend to focus on particular aspects of social interaction (Rogers, 2000). Studies focus on starting the social interaction, establishing eye contact, and especially common attention skills. It is believed that there are limitations in experimental findings regarding the skills of initiating and maintaining the interaction and responding that cover social interaction as a whole, and including the family in the process of supporting the social interaction skills (Cassel et al., 2007; Mundy, Sigman and Kasari, 1990; Rogers, 2000, Sigman and Ruskin, 1999; Stone, Ousley, Yoder, Hogan, and Hepburn, 1997; Wetherby, Prizant, and Hutchinson, 1998).

It is believed that more detailed information will be obtained by measuring the social interaction skills of children with ASD using detailed observation records in this study. Additionally, considering the studies conducted in the literature on the RT, it is observed that the RT does not focus on the social interaction problems that are very important for children with ASD. The objectives of this study are: a) to investigate the effect of the RT on the social interaction skills of children with ASD, and b) to investigate whether the RT is effective in maintaining the social interaction skills of children with ASD 2 months after completing the research practices.

\section{Method}

The study was conducted with three children with ASD attending a private special education and rehabilitation centre and their mothers in 2012, within the borders of Ankara province. In terms of the genders of the participant children, one of them is female, and the other two are male. The age of the first participant child is 6 as of the starting date of the study, the second participant child is 4 years old, and the third participant child is 3 years and 2 months old. The ages of the participant mothers are between 33 and 35 years.

In this study, the effect of the RT on the social interaction skills of the child participants was collected using the pre-application, during application and post-application observation data. The inter-subject 
multiple baseline design among single subject experimental patterns was used in this study. The effectiveness of the application was investigated by comparing the starting level stage and application stage data in each situation.

The independent variable of the study is the RT (Diken, 2012; Mahoney and MacDonald, 2007). The dependent variable of the study is the social interaction levels of child participants. The social interaction skills of the children with ASD were examined in three sub-categories; 1) Starting the interaction, 2) Responding to the interaction, 3) Maintaining the interaction. The data on the social interaction skills of children were measured by means of analyzing video surveys.

The application process of the study was performed in four stages. These stages are the determination of the starting levels of the participants, the application of the RT, post RT assessment and follow-up.

In the collection of the data in the study, the effect of the program applied on the social interaction skills of children with OSB was ensured by incorporating the collection and coding of the observation data.

In this study, application safety data were collected in order to determine whether the application sessions of the RT were applied correctly by the researcher. At this stage, the application reliability for each stage was found to be $100 \%$.

The interobserver reliability data regarding the data on measuring the social interaction skills of children directly were determined. In this study, 107 session observation data in total were collected for three children who participated in the study. Interobserver reliability was found to be at an average level of $83 \%$ for 10 randomly selected observation data for the first child, being at least $81 \%$ and at most $85 \%$; at an average level of $87.5 \%$ for 11 randomly selected observation data for the second child being at least $83 \%$ and at most $92 \%$; and at an average level of $88 \%$ for 12 randomly selected observation data for the third child being at least $84 \%$ and at most $92 \%$. The interobserver reliability of all the data, $30 \%$ of which were randomly selected, was calculated at the average level of $86 \%$.

In this study, the visual analysis of the data presented with the graph was performed using the intersubject multiple baseline design among single subject patterns. In the analysis of the social interaction skills of children, the pre-application, during and post-application observation data were presented with a line graph that suits the multiple baseline design. The observational data that examine whether the RT has any effect on the social interaction skills of children, if so, the number of starting the interaction and the duration of maintaining the interaction by including three sessions each from the starting level stage, application stage and follow-up stages for each child participant into coding in order to be able to collect data on its frequency and duration.

\section{Results}

As a result of the study, it was determined that children exhibited positive advancements in their social interaction skills. At the end of the study, it was observed that there was a high- level increase in the 
social interaction skills of each participant child. While the social interaction skills exhibited by three participant children in a free playing environment with their mothers, their level of starting the interaction with their mothers, responding and maintaining the interaction with the mother at the baseline level were low; a major increase was determined in the behaviours of starting the social interaction with the mother, responding to the interaction and maintaining the interaction following the application of the RT.

\section{Conclusion and Discussion}

It is also among the most distinctive features of this work that children with ASD focus on social interaction skills that are at the top of the most restricted areas. The findings of the research provide implications for practitioners. First, family-centered and family-directed practices recommended for young children with disabilities should take a greater role in early ASD interventions; because these findings have shown potential effectiveness for such approaches. Second, creating an intervention based on parent-child relationship should be a priority, especially for children with early-onset ASD. The third is based on parent-child interactions occurring in natural family settings, which suggests that services for young children with OSD should be examined in light of the present findings. 


\section{GİRIS}

Otizm Spektrum Bozukluğu (OSB), erken çocukluk döneminde ilk belirtilerini gösteren, bireylerin sosyal etkileşim ve iletişim becerilerini olumsuz yönde etkilemesiyle birlikte takıntılı, yineleyici davranışlar ve ilgi alanlarında sınırlılıklar ile kendini gösteren gelişimsel bir bozukluktur (Amerikan Psikiyatri Birliği, 2013). Amerikan Psikiyatri Birliği tarafından hazırlanan DSM 5 temel başvuru kılavuzuna göre, OSB tanısı için kullanılan iki ana ölçüt bulunmaktadır. Bu ölçütlerden ilki sosyal etkileşim/ iletişim problemleri ve ikincisi sınırlı ve yineleyici ilgi, davranış ve etkinliklerdir (Amerikan Psikiyatri Birliği (APA), 2013).

OSB'nin tanılanmasında kullanılan sosyal etkileşim becerilerindeki yetersizlik ölçütü, çocukların gelişim düzeyi dikkate alındığında sosyal etkileşim becerilerinde sergiledikleri nitel bozulmaları kapsamaktadır. Bu ölçütün, davranışsal belirtileri arasında göz kontağı, taklit ve jestleri çok sınırlı kullanım yer almaktadır (Alvarez, 1999; APA, 2013; Carter, Gillham, Sparrow ve Volkmar, 1996). Genellikle akranları ya da yetişkinlerle etkinliklere katılmada sınırlılıklar ve başkaları ile etkileşimi başlatma ve sürdürme sorunları, OSB'li çocukların sosyal etkileşim becerilerindeki yetersizliklerle ilişkilidir. $\mathrm{Bu}$ bağlamda OSB'li çocukların sosyal etkileşim becerileri gelişimini olumsuz etkileyen sınırlılıklarının başında, sözsüz/sözlü uyaranlara cevap verme, sosyal dikkati sağlama ve etkileşime katılmayı gerektiren beceriler yer almaktadır (Frith ve Frith, 2001; Hobson, 1993). OSB'nin tanılanmasında kullanılan ölçütler arasında yer alan iletişim problemlerinde, sosyal etkileşim becerilerinde olduğu gibi iletişim becerilerinde gözlemlenen nitel bozulmalar açıklanmaktadır. Dil kullanımında gecikme ya da dili hiç kullanmama, konuşmanın geliştiği durumlarda iletişimi başlatma ya da sürdürmede güçlükler, sembolik oyun ve taklit gerektiren etkileşimlere kendiliğinden katılmama bu ölçütün davranışsal göstergeleri arasındadır (APA, 2013; Baker, Messinger, Lyons ve Grantz, 2010; Layton ve Watson, 1995). OSB'de görülen bu problemler, çocuğun gelişimini, etrafindaki kişilerle etkileşim ve iletişimini, yaşamın ilk dönemlerinden başlayarak olumsuz yönde etkilemektedir (Mundy ve Newell, 2007).

Normal gelişim gösteren çocuklar, aileleriyle, akranlarıyla etkileşim kurarlarken geniş bir sosyal etkileşim aralığı kullanmaktadırlar (mimikler, jestler, konuşma, sosyal ilişkilendirme ve yüz ifadeleri gibi) (Charlop, Dennis, Carpenter ve Greenberg, 2010). Bu durumun aksine, OSB'li çocuklar sosyal etkileşim becerilerini kullanmada önemli problemler sergilemektedirler (Charlop vd., 2010). OSB'li çocuklar diğer insanlarla etkileşime girmeye daha az ilgi gösterirler. Yalnız oynamayı daha çok tercih eder, arkadaşlık kurma becerileri ve oyun arkadaşı 
olarak tercih edilmeleri daha sınırlı ve etkileşim kurma nitelikleri düşük düzeydedir (Baker vd., 2007; Charlop vd., 2010; Cotugno, 2009; McConnell, 2002).

Sosyal etkileşim becerileri sınırlı olan çocuklar, çoğunlukla, aileleri ve akranları ile bir araya gelerek sosyal etkileşim içinde bulunma ve etkileşimi sürdürme problemleri sergilemektedirler. OSB'li çocukların sosyal etkileşim becerilerinde yeterli olabilmesi için, sosyal etkileşimi başlatabilmeleri, sosyal uyarana uygun cevap verebilmeleri, sözel etkileşimde sıra alabilmeleri, sosyal etkileşimi devam ettirebilmeleri gerekmektedir (Beckman ve Leiber, 1994; CraigUnkefer ve Kaiser, 2002). Oysa ki aile ve akranlarla girilen etkileşimler sırasında, ihtiyaçlar ve istekler konusunda iletişim kurma becerisinde sınırlılıklar yaşama, aileler tarafından anlaşılamama, akranlar tarafından reddedilme gibi olumsuz sosyal etkileşim sonuçlarına yol açabilmektedir (Craig-Unkefer ve Kaiser, 2002). Ayrıca, akranları tarafından reddedilen çocuklar, sınırlı düzeyde sosyal etkileşim becerileri nedeniyle, giderek daha saldırgan ve uyumsuz davranışlar sergileyebilmektedirler (Bierman ve Wargo, 1995). Yetersiz iletişim ve sosyal etkileşim becerileri, yetişkinlerle, ailelerle ve akranlarla etkileşime girilmesini güçleştirmekte ve bu durumda, okul öncesi yıllarda artan düzeyde problem davranışların oluşmasına neden olmaktadır. Söz konusu beceri eksikliklerine müdahale edilmemesi halinde ise, bu döngü devam etmektedir (Clarizio, 1997).

Çocuklar doğdukları andan itibaren okula başladıkları döneme kadar birçok beceriyi ailelerinden öğrenirler. $\mathrm{Bu}$ anlamda da ailelerin, çocuklarının gelişiminde doğum öncesinden başlayarak yaşamlarının sonuna kadar önemli sorumlulukları olduğu kabul edilmektedir. Erken yaşlarda çocuğun içerisinde bulunduğu çevre ve çocuğa sağlanan eğitimin niteliği çocuğun gelecekteki başarılarını dolayısıyla da yaşam kalitesini büyük ölçüde belirlemektedir. Çocuğun doğduğu andan itibaren eğitiminde çok önemli yeri olan anne babaların, çocuklarına daha yararlı olabilmeleri, aile eğitimi aracılığıyla mümkündür (Bekman, 1998; Solomon, Necheles, Ferch ve Bruckman, 2007). Nitekim, ailelere gereksinimleri olan bilgileri kazandırmayı amaçlayan aile eğitimi, ailelerin çocuklarının yeterliliklerini ve gelişimlerini destekleyebilecekleri bilgileri kazandırmak ve çocuklarının gelişimlerini destekleyici becerileri edinmelerini sağlamak için uzmanlar tarafından sistematik olarak yürütülen önemli bir süreç olarak tanımlanmaktadır (Mahoney, Kaiser ve Girolametto, 1999). OSB'li çocukların erken eğitimlerinde, ailelerin çocuğunun eğitimine katılımının kritik derecede önemli kabul edilmesinin yanı sıra, tüm özel gereksinimli çocuklarda, aile ile beraber çocuğun gelişimine müdahale edilmesi genel kabul gören bir yaklaşımdır (Mahoney vd., 1999). 
OSB'li çocuklarda sosyal etkileşim becerileri sınırlılığına yönelik olarak, sosyal etkileşimin desteklenmesi, alanyazında var olan müdahale programlarının en önemli amaçlarından birisi olarak hedeflenmiştir (Mahoney vd., 1999; Rogers, 2000). Bu anlamda çeşitli müdahale programları desenlenmiş, deneysel açıdan etkililikleri incelenmiş ve OSB'li çocukların sosyal iletişim becerileri eğitimi alanyazını içerisinde yayımlanmıştır. Bu müdahaleler çeşitli biçimlerde birbirlerinden farklılaşmaktadırlar: Çalışmaya katılan OSB'li çocuk grubunun yaşı, müdahalenin hedef davranışı (başlatma, cevap/etkileşim, sürdürme, ortak dikkat, taklit, oyun vb.), çalışmaya katılan sosyal partnerin türü (akran veya yetişkin), kullanılan müdahale stratejisi ve müdahaleyi sunanın özellikleri (akran veya yetişkin) bunlardan bazılarıdır. Yayımlanmış müdahalelerin büyük kısmı, davranışçı bir metodolojiyi temsil etmektedir. Bu metodoloji içerisinde, kazanılması, artırılması veya azaltılması planlanan hedef davranışların ayrıntılı tanımları, yine hedef davranışın tetikleyicileri ve sonuçları hakkında tanımlar, hedef davranışın analizi, hedef davranışın çok daha doğal ve pekiştirici koşullar altında sürdürülebilmesi, davranış kazanımının ölçümü ve davranışın farklı ortamlara, kişilere ve davranışlara genellenmesi yer almaktadır (Dawson ve Galpert, 1990; Rogers, 2000; Simpson, Myles, Sasso ve Kamps, 1997).

$\mathrm{Bu}$ alanda gerçekleştirilmiş ilk çalışmaların, yetişkin merkezli bir öğretim içermiş ve belli oranda da etkili olduğu gösterilmiş olmasına rağmen (Dawson ve Galpert, 1990; Simpson, Myles, Sasso ve Kamps, 1997) alan yazında, çocukların doğal ortamlardaki ekolojisine daha fazla dikkat eden bir anlayışa ve sonrasında da akranlarla girilen sosyal etkileşimlere daha fazla odaklanmaya doğru bir kayma olduğu dikkat çekicidir (Rogers, 2000).

Her ne kadar sosyal etkileşimdeki sınırlılıklar OSB'nin erken göstergeleri arasında yer alsa da, sosyal beceri sınırlılıklarının ve gecikmiş sosyal gelişimin olası etkilerini iyileştirecek uygun müdahaleler genellikle sosyal etkileşimin belirli boyutlarına odaklanma eğilimi göstermektedir (Cassel vd., 2007; Mundy, Sigman ve Kasari, 1990; Rogers, 2000). Çalışmalar, sosyal etkileşimi başlatma, göz kontağı kurma, özellikle de ortak dikkat becerilerine odaklanmaktadır (Rogers, 2000; Sigman ve Ruskin, 1999; Stone, Ousley, Yoder, Hogan ve Hepburn, 1997; Wetherby, Prizant ve Hutchinson, 1998). Sosyal etkileşim davranışının alt boyutlarını tek tek ele almak yerine, sosyal etkileşimin tüm boyutlarını kapsayan (etkileşimi başlatma, sürdürme, yanıt verme) becerilerle ilgili deneysel bulgularda ve aileyi sosyal etkileşim becerileri destekleme sürecine katmada sınırlılıklar olduğu düşünülmektedir.

Erken müdahale uygulamaları, çocukların gelişim aşamalarını ve aile-çocuk etkileşimini desteklemeyi temel almasına rağmen, erken çocuklukta verilen destek eğitim hizmetlerinin 
çocuklara ve ailelere en iyi şekilde nasıl sunulacağı özellikle son 30 yılda üzerine çok tartışma yapılan konulardan birisi haline gelmiştir (Özdemir, 2007; 2008; Özdemir ve Gürel, 2010). OSB'li çocuklara yönelik müdahalelerin ve teori yaklaşımlarının uygulamalara yansımalarını anlamak için, tek bir yaklaşım ya da birden fazla yaklaşımın birleştirildiği müdahaleleri dikkate almak önemlidir. Çocukların etkileşim becerilerinin en erken zamanlarda oluşmaya başlaması, verilen eğitimin sürekliliğinin sağlanabilmesi ve sosyal etkileşim becerilerinin gelişiminin devamlılığı için, ailenin eğitime katılması OSB'li çocuklarda uygulanan erken müdahalenin en önemli parçası olarak kabul edilmektedir (McConachie ve Diggle, 2007; Wetherby ve Prizant, 2000). Nitekim OSB'li çocukların eğitiminde en önemli sorunlardan birisi, verilen eğitimin sürekliliğinin sağlanamamasıdır. $\mathrm{Bu}$ sorun OSB'li çocukların, erken dönemde aileleriyle etkileşim fırsatlarının desteklenmesi ile çocuğun gelişim alanlarında daha fazla ilerlemelerin oluşmasının sağlanacağı görüşü ile aşılabilecek gibi görünmektedir (Brookman-Frazee, Stahmer, Baker-Ericzen ve Tsai, 2006; Koyuncu, 2009; McConachie ve Diggle, 2007).

Günümüzde, OSB'li çocukların eğitimlerinde, ilişki temelli yaklaşımları (Greenspan ve Wieder, 1999; Klein, 2003; Prizant, Wetherby, ve Rydell, 2000) dikkate alan [örn., Early Start Denver Model, DIR-Floortime, Enhanced Milieu Teaching $\{$ EMT $\}$, Pivotal Response Training $\{$ PRT $\}$, orijinal adı ile Responsive Teaching \{RT \} olan Etkileşim Temelli Erken Çocuklukta Müdahale Programı \{ETEÇOM-RT\}], çocukların gelişimleri çerçevesinde sosyal iletişim ve etkileşim ihtiyaçlarını karşılamaya yönelik erken eğitim müdahaleleri ön plana çıkarmaya başlamıştır (Schertz ve Odom, 2007). İlişki temelli yaklaşımda, ebeveyn (birincil bakıcı)-çocuk etkileşimine önem verilmekte, ortak dikkat, etkileşimi başlatma, sürdürme gibi sosyal etkileşim becerileri de (birincil bakıcı)-çocuk etkileşimi aracılığıyla desteklenmektedir (Kaiser ve Hemmeter, 1996; Mahoney ve Perales, 2003). İlişki temelli yaklaşımların öncelikli olarak aileler tarafından gerçekleştirilen uygulamalar olması, OSB'li çocuklarla uygulanan müdahalelerde bir avantaj olarak görülmektedir. Kaiser ve Hancock (2003) ailelere çocuklarıyla etkileşimlerinde kullanabilecekleri, çocukların gelişimsel gereksinimlerine uygun stratejileri öğretmeyi hedefleyen, öğretime doğal ortamlarda farklı zamanlarda ve yerlerde yer veren uygulamaların, etkililiğinin, genellemesinin ve kalıcılığının yüksek olacağını ileri sürmektedirler. Ingersoll ve Gergans'da (2007) eğitim uygulamalarının erken çocukluk döneminde aileler tarafından gerçekleştirilmesi durumunda, hizmetin çocuklara doğrudan sağlanacağını ve daha az zaman harcanacağını ileri sürmektedirler.

İlişki temelli yaklaşıma dayalı uygulamalar, çocukların sosyal-duygusal ve gelişimsel ihtiyaçlarına işaret etmekte ve ebeveynlerin (birincil bakıcıların), kendi çocukları ile daha 
yanıtlayıcı bir şekilde etkileşime girmelerine destek olmak için geliştirilen stratejileri içeren bir yaklaşım olarak benimsenmektedir (Mahoney ve Perales, 2005). İlişki temelli uygulamalar, çocuk gelişimi kuramı ve erken müdahale araştırmalarının desteklediği iki temel varsayıma dayanmaktadır: (1) Ebeveynler (birincil bakıcılar), çocuklarının gelişimi üzerinde uzmanlara ve diğer yetişkinlere oranla daha fazla etkiye sahiptirler, çünkü çocuklarının gelişimini sağlayacak ve onları destekleyecek daha fazla zaman ve olanaklara sahiptirler ve (2) Ebeveynler (birincil bakıcılar), çocuklarıyla yoğun etkileşime girerek onların gelişimlerini destekleyebilirler. $\mathrm{Bu}$ görüş, ailelerin çocuklarıyla kurdukları karşılıklı etkileşim davranışlarının, çocukların gelişimindeki olumlu ilerlemelerle ilişkili olduğunu gösteren çocuk gelişimi araştırmalarının sonuçlarına dayanmaktadır (Mahoney ve Perales, 2008). Çocukların ebeveynleri ile girdiği karşılıklı etkileşim ile çocukların bilişsel, dil ve sosyal-duygusal gelişimleri arasındaki ilişkiyi inceleyen araştırmalarda, sonuçlar ebeveyn-çocuk etkileşiminde, karşılıklı etkileşim artışının çocukların gelişim alanlarında gösterdikleri ilerlemelerle doğru orantılı olduğunu göstermektedir (Kim ve Mahoney, 2005). Alanyazında, ilişki temelli uygulamaların, gelişimi risk altında olan ya da gelişim geriliği gösteren çocuklar üzerindeki etkilerini inceleyen çalışmalar mevcuttur (Kaiser ve Hemmeter, 1996; Karaaslan, 2010; Karaaslan, Diken ve Mahoney, 2011; Kim ve Mahoney, 2004; Mahoney ve Perales, 2003, 2005). Bu çalışmalar, haftalık oturumlar halinde düzenlenen, doğrudan aileler ve çocuklarla çalışılarak, ailelere çocukları ile daha yanıtlayıcı bir biçimde etkileşime girme stratejilerinin öğretildiği eğitimler şeklinde yürütülmüştür. İlişki temelli yaklaşım esas alınarak oluşturulmuş bir program olan RT, Mahoney ve MacDonald tarafindan 2006 yılında program haline getirilmiştir. RT ailelerin ya da uzmanların etkileşim davranışlarını geliştirerek çocuğun bilişsel, iletişim ve sosyal gelişim alanlarında temel davranışları kazanmasını hedeflemektedir. RT, 2013 yılında Diken tarafından ETEÇOM adıyla Türkçe’ye uyarlanmıştır. Program Türk çocukları ve anneleri ile uygulanmaya başlanmıştır (Karaaslan, 2010; Toper-Korkmaz, 2015). ETEÇOM-RT (Diken, 2013; Mahoney ve McDonald, 2007), çocukların, sosyal oyun başlatma, problem çözme, konuşma, ortak dikkat, güven, işbirliği ve yeterlilik duygusu gibi öğrenmeye temel oluşturabilecek temel davranışları geliştirmelerini ve kullanmalarını teşvik etmektedir. Etkileşime dayalı öğretimde yer alan eğitsel stratejiler, yetişkinlerin, çocukları ile girdikleri günlük rutinlere kolayca entegre edebilecekleri hatırlanması kolay önerileri içermektedir.

Özet olarak, alan yazında sosyal etkileşim becerisinin, araştırmacılar tarafından farklı perspektiflerden ele alındığı, sosyal etkileşimin belirli boyutlarına odaklanıldığg görülmekte bu nedenle bütüncül bir perspektifle incelenmesi gerektiği düşünülmektedir. Tüm bu tartışmalar 
doğrultusunda, ETEÇOM Programı'nın tüm gelişim alanlarını ilerletmeye yönelik bütüncül bir program olması, bu gelişim alanları içerisinde iletişim ve sosyal duygusal alanlara yönelik stratejileri kapsamasından dolayı OSB'li çocukların sosyal etkileşim becerilerini destekleyeceği düşünülmektedir. Aynı zamanda bu çalışma ile bütüncül bir perspektif ortaya koyarak OSB'li çocukların sosyal etkileşim becerilerinin boyutları olan etkileşim başlatma, etkileşime yanıt verme ve etkileşimi sürdürme becerilerine bütüncül olarak bakılması alan yazına katkı sağlayacağı varsayılmaktadır.

$\mathrm{Bu}$ araştırma ile OSB'li çocukların sosyal etkileşim becerileri ayrıntılı gözlem kayıtları ile ölçülerek daha ayrıntılı bilgiler elde edileceği düşünülmektedir. Ek olarak ETEÇOM Programı'na ilişkin alan yazında yapılan çalışmalar göz önüne alındığında, ETEÇOM Programı'nın OSB'li çocuklar için büyük önem taşıyan sosyal etkileşim problemlerine odaklanmadığı görülmektedir. Bu araştırmanın genel amacı, ETEÇOM Programı'nın, OSB'li çocukların sosyal etkileşim becerileri üzerindeki etkisini incelemektir. Bu amaçla araştırmada aşağıdaki sorulara cevap aranmıştır:

1. Etkileşim Temelli Erken Çocuklukta Müdahale Programı'nın, OSB'li çocukların sosyal etkileşim becerilerine etkisi var mıdır?

2. Etkileşim Temelli Erken Çocuklukta Müdahale Programı, araştırma uygulamaları tamamlandıktan 2 ay sonra OSB'li çocukların sosyal etkileşim becerilerini sürdürmede etkili midir?

\section{YÖNTEM}

\section{Katılımcılar}

Araştırma, Ankara İli sınırlarında 2012 yılı içerisinde özel özel eğitim ve rehabilitasyon merkezine devam eden üç OSB'li çocuk ve çocukların anneleri ile gerçekleştirilmiştir. Araştırmaya katılan katılımcıların seçiminde; a) 36-72 ay yaş diliminde olması, b)Yetersizliğe ilişkin klinik tanı almış olması (Devlet hastaneleri ve Üniversite hastanelerinin, çocuk psikiyatri bölümlerinden), c) OSB haricinde ek bir yetersizlik tanısı almamış olması, d) Gazi Erken Çocukluk Değerlendirme Aracı'nın (GEÇDA; Temel, Ersoy, Avcı ve Turla, 2004), uygulanması sonucunda, gelişim alanlarının birbirine yakın düzeyde olması, e) Uygulama sertifikasına sahip olan araştırmacı tarafından Gilliam Otistik Bozukluk Derecelendirme Ölçeği-2-Türkçe Versiyonu (GOBDÖ-2-TV; Diken, Ardıç ve Diken, 2011) uygulaması sonucunda, ölçek karar rehberi doğrultusunda, otistik bozukluk indeksi puanı en az 85 ve daha 
yüksek puan almış olması, f) Anne-çocuk serbest oyun etkinliği sırasında alınan 15'er dakikalık çocukların temel davranışlarının ölçümlendiği Çocuk Davranışını Değerlendirme ÖlçeğiTürkçe Versiyonu (ÇDDÖ-TV, Diken, 2009) değerlendirmesinin sonucunda, ölçek karar rehberi doğrultusunda temel davranışların düşük düzeyde olduğuna karar verilmesi, ancak ölçek puanı doğrultusunda en fazla 16 puan alınmış olması (ölçekten en fazla 35 puan alınmakta) temel seçim ölçütleri olarak kabul edilmiştir. Anne katılımcılar için; a) Sosyoekonomik düzeylerinin birbirine yakın özellikte olması, b) Annelerin son bir sene içerisinde ETEÇOM benzeri bir programa katılmamış olması, c) Anne-çocuk serbest oyun etkinliği sırasında alınan 15'er dakikalık annelerin etkileşim davranışlarının ölçümlendiği Ebeveyn Davranışını Değerlendirme Ölçeği-Türkçe Versiyonu (EDDÖ-TV, Diken, 2009) değerlendirmesinin sonucunda, ölçek karar rehberi doğrultusunda annelerin etkileşim davranışların düşük düzeyde ve başarı odaklı olma ve yönlendirici olma davranışlarının yüksek düzeyde olması ve d) Çalışmaya gönüllü olarak katılmayı istemeleri temel seçim ölçütleri olarak kabul edilmiştir.

\section{Birinci Katılımcı Çocuk}

Birinci katılımcı çocuk, çalışmaya başlandığı tarih itibariyle 6 yaşında olan ve üniversite hastanesi tarafından OSB tanısı almış olan bir erkek çocuktur. Yaklaşık üç yıldır özel özel rehabilitasyon merkezine devam etmektedir. Haftada üç saat bireysel, bir saat grup eğitimi almaktadır. OSB dışında herhangi bir ek yetersizliği bulunmamaktadır. 2-3 kelimelik karmaşık olmayan cümleler kurabilmektedir. ÇDDÖ-TV kodlanması sonucunda birinci katılımcı çocuğun temel davranışlarından (dikkat, devamlılık, katılım, işbirliği, başlatma, ortak dikkat ve duygusal durum) ortalama 2 puan aldığı, ÇDDÖ-TV puanlama el kitabına göre temel davranışlarının düşük düzeyde olduğu belirlenmiştir. GOBDÖ-2-TV ölçeğinde Stereotip Davranışlar alt ölçeğinden aldığı ham puan 8, İletişim Davranışları alt ölçeğinden aldığı ham puan 35, Sosyal Etkileşim Davranışları alt ölçeğinden aldığı ham puan17'dir. Otistik Bozukluk İndeksi puanı 103'dür ve bu sonuçlara göre ölçek karar rehberi doğrultusunda birinci katılımcı çocuğun Otistik Bozukluk Görülme Olasılığı oldukça yüksektir. GEÇDA ölçeğinde, çocuğun Psikomotor Becerileri alt testinden aldığı puan 70, Bilişsel Gelişim alt testinden aldığı puan 48, Dil Gelişimi alt testinden aldığı puan 53 ve Sosyal-Duygusal Gelişimi alt testinden aldığı puan 51 'dir. Bu puanlar ölçekte alt sınır olarak değerlendirilmektedir.

\section{İkinci Katılımcı Çocuk}

İkinci katılımcı çocuk, çalışmaya başlandığı tarih itibariyle 4 yaşında olan ve üniversite hastanesi tarafından OSB tanısı almış olan bir erkek çocuktur. Yaklaşık bir yıldır özel özel 
rehabilitasyon merkezine devam etmektedir. Haftada iki saat bireysel, bir saat grup eğitimi almaktadır. OSB dışında herhangi bir ek yetersizliği bulunmamaktadır. 5-6'yı geçmeyen tek kelime çıkarmakta ve seslendirmelere yer vermektedirler. ÇDDÖ-TV kodlanması sonucunda ikinci katılımcı çocuğun temel davranışlarından (dikkat, devamlılık, katılım, işbirliğgi, başlatma, ortak dikkat ve duygusal durum) ortalama 1 puan aldığı, ÇDDÖ-TV puanlama el kitabına göre temel davranışlarının çok düşük düzeyde olduğu belirlenmiştir. GOBDÖ-2-TV ölçeğinde Stereotip Davranışlar alt ölçeğinden aldığı ham puan 11, İletişim Davranışları alt ölçeğinden aldığg ham puan 32, Sosyal Etkileşim Davranışları alt ölçeğinden aldığı ham puan 21'dir. Otistik Bozukluk İndeksi puanı 105'dir ve bu sonuçlara göre ölçek karar rehberi doğrultusunda ikinci katılımcı çocuğun Otistik Bozukluk Görülme Olasılığı oldukça yüksektir. GEÇDA ölçeğinde, çocuğun Psikomotor Becerileri alt testinden aldığı puan 62, Bilişsel Gelişim alt testinden aldı ̆̆ puan 40, Dil Gelişimi alt testinden aldığı puan 50 ve Sosyal-Duygusal Gelişimi alt testinden aldığı puan 48'dir. Bu puanlar ölçekte alt sınır olarak değerlendirilmektedir.

\section{Üçüncü Katılımcı Çocuk}

Üçüncü katılımcı çocuk, çalışmaya başlandığı tarih itibariyle 3 yaş 2 aylıktır ve bir üniversite hastanesi tarafından OSB tanısı almış olan bir kızdır. Yaklaşık bir buçuk yıldır özel özel rehabilitasyon merkezine devam etmektedir. Haftada üç saat bireysel eğitim almakta ve yarım zamanlı kreşe gitmektedir. OSB dışında herhangi bir ek yetersizliği bulunmamaktadır. 5-6'yı geçmeyen tek kelime çıkarmakta ve seslendirmelere yer vermektedirler. ÇDDÖ-TV kodlanması sonucunda üçüncü katılımcı çocuğun temel davranışlarından (dikkat, devamlılık, katılım, işbirliği, başlatma, ortak dikkat ve duygusal durum) ortalama 1 puan aldığı, ÇDDÖTV puanlama el kitabına göre temel davranışlarının çok düşük düzeyde olduğu belirlenmiştir. GOBDÖ-2-TV ölçeğinde Stereotip Davranışlar alt ölçeğinden aldığı ham puan 23, İletişim Davranışları alt ölçeğinden aldığı ham puan 27, Sosyal Etkileşim Davranışları alt ölçeğinden aldığg ham puan 20'dir. Otistik Bozukluk İndeksi puanı 114'dür ve bu sonuçlara göre ölçek karar rehberi doğrultusunda üçüncü katılımcı çocuğun Otistik Bozukluk Görülme Olasılığı oldukça yüksektir. GEÇDA ölçeğinde, çocuğun Psikomotor Becerileri alt testinden aldığı puan 57, Bilişsel Gelişim alt testinden aldığı puan 37, Dil Gelişimi alt testinden aldığı puan 46 ve SosyalDuygusal Gelişimi alt testinden aldığı puan $48^{\prime}$ dir. Bu puanlar ölçekte alt sınır olarak değerlendirilmektedir.

\section{Katılımci Anneler}

Katılımcı annelerin hepsi çalışmaya katılmaya gönüllü olan, ETEÇOM benzeri bir eğitim almamış olan annelerdir. Katılımcı annelerin yaşları 32-35 arasında değişmektedir. İki katılımcı 
anne üniversite mezunudur ve çalışmaktadır, biri lise mezunu ve ev hanımıdır. Sosyo-ekonomik durumları iki katılımcı annenin yüksek diğer annenin orta düzeydedir. İki katılımcı annenin bir çocuğu, diğer annenin iki çocuğu bulunmaktadır. Çocukları ile etkileşim davranışlarının ölçümlendiği EDDÖ-TV değerlendirmesinin sonucunda ölçek karar rehberi doğrultusunda katılımcı annelerin etkileşim davranış stilleri, düşük düzeyde duyarlı ve yanıtlayıcı davranışları içerirken, daha çok başarı odaklı ve yönlendirici oldukları belirlenmiştir.

\section{Ortam}

Bu araştırmanın uygulamaları 2012 yılında, Ankara'da Gazi Üniversitesi Öğrenme Gelişim Eğitim Uygulama ve Araştırma Merkezi (ÖGEM) ile bir katılımcı çocuğun devam ettiği kurumda (özel özel eğitim ve rehabilitasyon merkezi) gerçekleştirilmiştir. Her iki kurumda, yaklaşık yirmi metrekare olan iki bireysel çalışma sınıfı bulunmaktadır. Sınıflarda bir dolap küçük çocuklara yönelik olarak çeşitli oyun setleri, eğitim materyalleri, çocuğun boyuna uygun bir masa ve sandalyeler bulunmaktadır. Ayrıca sınıfın bir köşesinde yerde çalışmaya uygun olarak oluşturulmuş minderler yer almaktadır. Kapalı devre kamera sistemi ile yapılan etkinlikler kaydedilmiştir. Ayrıca odanın içine bir el kamerası yerleştirilerek uygulamalar kaydedilmiştir. Araştırmanın izleme oturumları ise katılımcıların evlerinde doğal ortamlarında gerçekleştirilmiştir. Araştırmanın uygulandığı odalarda, odanın tabanına halı serilerek etkileşimlerin yerde gerçekleştirilmesine olanak verilmiştir. Ayrıca masa başı etkinliklerle etkileşime olanak vermek amacıyla çocukların fiziksel özelliklerine uygun masa ve üç sandalye bulundurulmuştur. Çocukların anneleriyle etkileşimleri sırasında kullanabilecekleri oyuncaklar (örn. oyuncak araba, legolar, evcilik seti, çiftlik hayvanları, oyun hamuru gibi) ve masa başı etkinlikleri için araç-gereçler (örn., kağıt, boya kalemi, makas vb.) bulundurulmuştur.

\section{Araştırma Deseni}

$\mathrm{Bu}$ araştırmada, ETEÇOM Programı'nın çocuk katılımcıların sosyal etkileşim becerilerine etkisi uygulama öncesi, sırası ve sonrası gözleme dayalı veriler yoluyla toplanmıştır. $\mathrm{Bu}$ araştırmada tek denekli deneysel desenlerden çoklu başlama düzeyi deseni uygulanmıştır. Her bir durumdaki başlama düzeyi evresi ve uygulama evresi verileri karşılaştırılarak uygulamanın etkililiği incelenmiştir. Bu araştırmada birinci çocuk için üç, ikinci çocuk için altı, üçüncü çocuk için on bir oturum başlama düzeyi verisi, üç çocuk için yirmi dört oturum uygulama verisi ve beş oturum da izleme verisi toplanmıştır. Çoklu başlama düzeyi deseni uygulanırken ilk olarak üç çocuk ile eş zamanlı üç oturum başlama düzeyi verisi toplanmıştır. Birinci çocuk ile başlama düzeyinde tutarlı sosyal etkileşim verileri alındıktan sonra ETEÇOM Programı'yla belirlenen stratejilerin öğretimi yapılmış ikinci ve üçüncü çocuk ile başlama düzeyi verileri alınmaya 
devam edilmiştir. Birinci çocukta uygulamanın etkisi gözlemlendikten ve ikinci çocukta başlama düzeyinde tutarlı sosyal etkileşim verileri alındıktan sonra ikinci çocuk ile ETEÇOM Programı oturumlarına başlanmış üçüncü çocuk ile başlama düzeyi verileri alınmaya devam edilmiştir. İkinci çocukta uygulamanın etkisi gözlemlendikten ve üçüncü çocukta başlama düzeyinde tutarlı sosyal etkileşim verileri alındıktan sonra üçüncü çocuk ile ETEÇOM Programı oturumlarına başlanmıştır. Denekler arası çoklu başlama düzeyi deseni uygulanırken belirlenen ölçüt, sosyal etkileşimi başlama düzeyi evresinin son üç oturumunun yüzdesinden \%40'lık bir artış sergilendiğinde ve veriler kararlılık gösterdiğinde diğer durumlara geçilmektir. Tüm çocuklarla araştırmanın uygulama evresi bitirildikten iki ay sonra izleme oturumu uygulanmıştır.

\section{Bağımsız Değişken}

Araştırmanın bağımsız değişkeni, ETEÇOM Programıdır (Diken, 2013; Mahoney ve MacDonald, 2007). ETEÇOM Programı, zamanlarının büyük bölümünü, küçük yaştaki çocuklara bakarak ve dolayısıyla da onlarla etkileşerek geçiren ebeveynler ve diğer bakıcılar tarafından uygulanması amacıyla tasarlanmış, çocuk gelişimi ile ilgili bir erken müdahale müfredatıdır. Araştırmada OSB'li çocukların sosyal etkileşim becerileri üzerine etkisini belirlemek amacıyla ETEÇOM Program'ı uygulanmıştır.

\section{Bağımlı Değişken}

Araştırmanın bağımlı değişkeni, çocuk katılımcıların sosyal etkileşim düzeyleridir. Bu araştırmanın bağımlı değişkeni olan OSB'li çocukların sosyal etkileşim becerilerinin tanımlanmasında sosyal etkileşim becerilerine yönelik yapılan araştırmalar incelenmiştir. Alan yazının incelenmesi sonucunda bu araştırmada, OSB'li çocukların sosyal etkileşim becerileri üç alt kategoride gözlemlenmiştir; 1) Etkileşimi başlatma, 2) Etkileşime yanıt verme, 3) Etkileşimi sürdürme. Çocukların sosyal etkileşim becerilerine yönelik veriler, video yoklamalarının analiz edilmesi yoluyla ölçülmüştür.

Sosyal etkileşim gözlem verileri üç davranış kategorisini içermektedir. Bunlar: 1. Etkileşimi Başlatma: Davranışsal tanım; Çocuğun annesine yönelttiği, sesli/sözlü veya jest/mimik davranışlarını içermektedir. Davranış örnekleri; Selamlaşma, paylaşma, yardım etme, yardım isteme, dokunma, yorum yapma, annesinin adını söyleme, yönerge verme, soru sorma, anneyi taklit ederek tepki verme etkileşim başlatma olarak puanlanmaktadır. Aynı zamanda aynı oyun materyalini farklı şekilde kullanarak eş zamanlı olarak anneye yönelmiş jest/mimik veya sesli/sözlü iletişimsel davranış gösterme, gülümseyerek ya da gülerek bir oyuncağı/ nesneyi 
anneye uzatma, gösterme, işaret etme /vererek anneye doğru gitme ya da bakma ve de sosyal bir yanıt alabilmek amacıyla doğrudan anneye yöneltilmiş herhangi bir motor ya da sesli davranışlar etkileşim başlatma olarak puanlanmaktadır. 2. Etkileşime Yanıt Verme: Davranışsal tanım; Annenin başlatmalarına 5 saniye içerisinde, sesli/sözel, sözel olmayan jest/mimik ile cevap vermeyi içermektedir. Davranış örnekleri; Annenin başlattığı etkinliği sürdürmeye yönelik ses çıkarma, konuşma, soru sorma, açıklama yapma, bir şey ya da yardım isteyerek ya da annenin söylediğini taklit ederek anneye tepki verme. Gülümseyerek ya da gülerek, bir oyuncağı/nesneyi anneye uzatarak, göstererek, işaret ederek ya da vererek, anneye doğru giderek ya da oyuncak/nesne götürerek, bakarak tepki verme davranışları etkileşime yanıt verme olarak puanlanmaktadır. 3. Etkileşimi Sürdürme: Davranışsal tanım; Başlatmalara ve annenin etkileşim yanıtlarına cevap verildiği ya da etkileşimin cevap sonrasında da devam ettiği durumları içermektedir. Davranış örnekleri; Sözel-sözel olmayan etkileşimde, anneye tepki olarak ya da kendi başlattığı etkinliği sürdürmek amacıyla sözel/sözel olmayan davranışlar sergilendiği zaman, anneyle birlikte oyuncaklarla sosyal oyun (araba, uçak, bebek) ya da fiziksel oyun (annenin çivileri tahtaya takması, birlikte şarkı söyleme) oynaması ve oyunu sürdürmesi, anne ve çocuğun aynı nesne ile ilgilenmesi ve çocuğun aktif olarak annenin katılımını kabul etmesi gibi davranışlar etkileşimi sürdürme olarak puanlanmaktadır (örn., örneğin çocuk annesine doğru kamyonu iter annesi de kamyonu iter çocuk anneye sonrada kamyona bakar; çocuk annesi ile aynı oyuncağın üzerine elini koyar ve anne oyuncağı kullanır, çocuk gülümser; çocuk uçağı uçurur annesine gösterir, annesi de gülümseyerek ya da uçak sesi yaparak katılımı kabul eder) (Ceber-Bakkaloğlu ve Sucuoğlu, 2000; Craig-Unkefer ve Kaiser, 2002; Lee, Odom ve Loftin, 2007; Schertz ve Odom, 2007).

\section{Araştırmada İç Geçerliliğin Sağlanması}

Denekler arası çoklu başlama düzeyi deseni iç geçerliliği yüksek bir desendir. Bu desende iç geçerlilik deneklere sağaltım uygulanmadan önce başlama düzeyinde bir değişiklik olmamasıyla, sağaltım uygulanınca ise belirlenen ölçüt düzeyde değişiklik olmasıyla kanıtlanır (Gast ve Ledford, 2010).

Araştırmada iç geçerliliği sağlamak amacıyla bazı etmenler kontrol altına alınmıştır;

a) Araştırmacı, katılımcıların, bağımlı değişkeni etkileyebilecek uygulamaları (sosyal etkileşim çalışmaları, oyun terapisi, etkileşim temelli aile eğitimleri) araştırmada uygulama süreci boyunca almamalarını sağlamak amacıyla katılımcıların anneleri ile görüşmeler yapılmıştır ve uygulama süresince herhangi bir başka eğitime katılmamaları gerektiği belirtilmiştir. Aynı zamanda katılımcıların öğretmenleri ile de görüşmeler yapılmış ve çocuklara oyunu ve sosyal 
etkileşimi destekleyecek herhangi bir çalışmaya yer vermemeleri rica edilmiştir. Bu şekilde dış etmenlerin etkisi kontrol altında tutulmaya çalışılmıştır;

b) Araştırmada olgunlaşma etkisi katılımcılardan başlama düzeyi verisi alınarak kontrol edilmiştir;

c) Araştırmada, verilerde ani değişkenlikler söz konusu olduğunda çocuğun annesiyle görüşmeler yapılmış ve yaşamlarında değişen herhangi bir durumun olup olmadığı araştırılmıştır. $\mathrm{Bu}$ süre zarfında çalışılan stratejiye devam edilmiştir;

d) Çocuklarla ve anneleriyle çalışmaya başlamadan bir hafta önce çalışmanın yapılacağı ortamda çalışılarak yapay ortam etkisi en aza indirilmeye çalışılmıştır.

\section{Uygulama Süreci}

Araştırma pilot ve deney süreci olmak üzere iki aşamada gerçekleştirilmiştir.

\section{Pilot Çalışma}

Deney sürecinde ortaya çıkabilecek olası aksaklıkları önceden belirleyebilmek, gerekli uyarlamaları gerçekleştirebilmek ve uygulamacının ETEÇOM Programı'na ilişkin günlük planın hazırlanması ve öğretimi ile ilgili deneyim sahibi olmasını sağlamak amacı ile pilot çalışma yapılmıştır. Pilot çalışmada araştırma için çalışma grubunda belirtilen gerekli olan ön koşul becerilere sahip OSB'li bir çocuk ile çalışılmıştır. Pilot çalışmada yer alan çocuk katılımcı, Ankara İlinde Rehberlik ve Araştırma Merkezi ve bulunduğu ildeki hastane tarafından (örn., üniversite ya da devlet hastanesi) OSB tanısına ilişkin onaylanmış rapora sahiptir.

Pilot çalışmanın yürütüldüğü dönemde OSB'li çocuk, 4 yaşındadır ve cinsiyeti erkektir. Yaklaşık olarak bir yıldır özel özel eğitim ve rehabilitasyon merkezine devam etmekte, haftada iki saat bireysel bir saat grup eğitimi almaktadır. Pilot çalışmada yer alan çocuğa ve annesine, ÇDDÖ-TV, EDDÖ-TV, GEÇDA ve GOBTÖ-2 TV ölçekleri uygulanmıştır. OSB'li çocuk-anne ikilisine 15-20 dakikalık oyun bağlamında sosyal etkileşim/temel davranışları ETEÇOM Programı uygulanmadan önce ÇDDÖ-TV ile kodlanmıştır. Bu kodlamalar sonucunda çocuk öntest toplam puanından 10 almıştır (ölçekten en fazla toplam 35 puan alınmaktadır). Bu kodlamalar sonucunda çocuğun dikkat alt faktöründen öntest toplam puanı 7 (ölçekten en fazla toplam 20 puan alınmaktadır) çocuğun ÇDDÖ-TV'nin ikinci alt faktörü olan başlatmadan öntest toplam puanı 3 'tür (ölçekten en fazla toplam 15 puan alınmaktadır). 
Anne-çocuk ikilisine 15-20 dakikalık oyun bağlamında annenin etkileşim davranışları ETEÇOM Programı uygulanmadan önce EDDÖ-TV ile kodlanmıştır. Bu kodlamalar sonucunda OSB'li çocuğun annesinin duyarlı-yanıtlayıcı olma alt faktöründen öntest toplam puanı 8 (ölçekten en fazla toplam 20 puan alınmaktadır), EDDÖ-TV'nin ikinci alt faktörü olan duygusal ifade edici olmadan öntest toplam puanı 9 (ölçekten en fazla toplam 25 puan alınmaktadır), EDDÖ-TV'nin üçüncü alt faktörü olan başarı odakl1-yönlendirici olma öntest toplam puanı 14 (ölçekten en fazla toplam 15 puan alınmaktadır fakat beklenen 9 puan alınmasıdır) çıkmıştır.

GEÇDA ölçeğinde, OSB'li çocuğun öntestte Psikomotor Becerileri alt testinden aldığı puan 63'tür, Bilişsel Gelişim alt testinden aldığı puan 40'dır bu puanlar ölçekte alt sınır olarak değerlendirilmektedir. Dil Gelişimi alt testinden aldığı puan 47 iken, Sosyal-Duygusal Gelişimi alt testinden aldığ 1 puan 45 çıkmıştır. Bu puanlarda ölçekte alt sınır olarak değerlendirilmektedir. Annenin görüşüne dayalı olarak doldurulan GOBDÖ-2-TV ölçeğinde, çocuğun öntestte Otistik Bozukluk İndeksi puanı 105'dir ve bu sonuca göre çocuğun Otistik Bozukluk Görülme Olasılığı oldukça yüksek çıkmıştır.

Pilot uygulama ÖGEM'de haftada iki gün gerçekleştirilmiştir. Üçüncü oturumun sonunda katılımcı anne çalışmadan ayrılmak istemiştir ve pilot çalışma tamamlanamadan yarıda bırakılmıştır. Çalışma yarıda kalmış olmasına rağmen ETEÇOM Programı'nın uygulanmasına ilişkin bazı düzenlemeler gerçekleştirilmiştir:

a) Pilot çalışma sonunda asıl uygulamaya geçmeden önce o günkü öğretim oturumu için belirlenen oyuncakların dışındaki diğer tüm oyuncaklar dolapta tutulmuştur. Oyuncakların ortamda olması çocukların dikkatinin sağlanmasında güçlük yaşanabileceği belirlenmiştir.

b) Pilot çalışmada günlük planların açıklanması, günlük planın anneye model olunması, rehberlik edilmesi ve ev ödevi planının oluşturulması aşamalarında uygulamacı, anne ve çocuk şeklinde yürütülürken, pilot çalışmanın sonunda ortamda bir başka kişinin dahil edilmesi sağlanmıştır. Anneyle daha önce uygulanan günlük plan hakkında konuşurken ve ev ödevi planı oluşturulurken, diğer kişinin (4. sınıf özel eğitim bölümü öğrencisi) çocukla oyun etkinlikleri gerçekleştirilmesine karar verilmiştir.

\section{Deney Süreci}

Araştırmanın deney süreci dört aşamada gerçekleştirilmiştir. Bu aşamalar, katılımcıların başlama düzeylerinin belirlenmesi, ETEÇOM Programı'nın uygulanması, ETEÇOM Programı sonu değerlendirme ve izlemedir. 


\section{Başlama Düzeyinin Belirlenmesi}

Araştırmanın uygulama sürecinde her bir çocuk için, çocukların sosyal etkileşim becerileri düzeylerini belirlemek amacıyla ardı ardına farklı günlerde üç oturum, başlama düzeyi verileri alınmıştır. Birinci çocuk için üç, ikinci çocuk için altı, üçüncü çocuk için on bir oturum başlama düzeyi verisi toplanmıştır. Anne çocuk ikilisinden, gelişimsel dönemlerine uygun olarak düzenlenmiş oyuncaklarla 10 ile 20 dakika süresince oyun oynamaları istenmiş ve oyun video kaydına alınmıştır. Annelerden, her zaman nasıl oynuyorlarsa, çocukları ile yine aynı şekilde oynamaları istenilmiştir.

\section{ETEÇOM Programı'nın Uygulanması:}

Uygulamada her bir anne-çocuk ikilisi ile haftada iki toplamda yirmi dört öğretim oturumu düzenlenmiştir. Öğretim oturumları araştırmacının kendisi tarafından gerçekleştirilmiş, oturumlar ortalama 1.5 saat sürmüştür (aileye o gün yapılacakların açıklanması, bilgi notlarının sunulması, etkileşimsel stratejilerin açıklanması, strateji kullanımının gösterilmesi, ailenin stratejileri kullanmasına rehberlik edilmesi, ev ödevi planının aileyle birlikte doldurulması). Her öğretim oturumunda o güne ilişkin günlük plan kullanılmıştır. Öğretim oturumları ETEÇOM Programı'nın uygulama kılavuzunda belirtildiği üzere aşağıdaki gibi uygulanmıştır.

\section{Günlük Planın Hazırlanması}

Günlük öğretim planları ETEÇOM kılavuzuna göre hazırlanmıştır. ETEÇOM kılavuzunda annelerin çocuklarıyla günlük etkileşimleri sırasında kullanabilecekleri, 16 temel davranış kazandırmaya yönelik 66 etkileşimsel strateji ve her bir etkileşimsel stratejisinin daha iyi anlaşılmasını sağlayan ve stratejilerin destekleyicileri niteliğinde olan 132 bilgi notu bulunmaktadır. Bilgi notları stratejilerden farklı olmakla birlikte stratejilere paralel bilgiler sunmaktadır. Günlük planda ikiden fazla olmaması kaydıyla en az bir strateji ve bilgi notu içerecek şekilde hazırlanması gerekmektedir. Uygulamacı, ETEÇOM' da bulunan 66 öğretimsel strateji ve 132 bilgi notunun tamamını çalışmak zorunda değildir. ETEÇOM Programı kılavuzunda stratejiler ve bilgi notları çocukların her bir gelişim alanına uygun olarak belirlenmiş, uygulama oturumları sırasında uygun strateji ve aileye açıklanacak bilgi notlarının seçimi uygulamacıya bırakılmıştır. Programda yer alan gelişim alanları için oluşturulmuş strateji ve bilgi notları bazen paralellik gösterebilmekte, bir strateji ya da bilgi notları birden fazla gelişim alanında yer almaktadır.

\section{Günlük Planın Anneye Açıklanması}


Uygulamac1, öğretim oturumuna o gün anne-çocuk etkileşiminde anneye kazandırmayı hedeflediği öğretimsel stratejiyi ve bu stratejiyi açıklayan bilgi notlarını anneye açıklayarak başlamıştır. Günlük planda anneye kazandırılması hedeflenen öğretim stratejileri ve bu stratejileri açıklayan bilgi notları yer almaktadır. Her bir öğretim stratejisi ve bilgi notları ETEÇOM'un uygulama kılavuzunda yer alan "Planlama ve İzleme Formu”ndan yararlanılarak belirlenmiştir. Anneye bu planlar açıklanırken, anne-çocuk ve uygulamacı araştırmanın yürütüldüğü odada, halıda oturmaktadır. Önlerinde çocuğun gelişimi için hazırlanmış oyuncaklar yer almaktadır.

\section{Günlük Planın Uygulanması}

$\mathrm{Bu}$ aşamada, uygulamacı anneye açıkladığı stratejileri, nasıl uygulayabileceğini göstermek amaçlı anneye model olmakta ve rehberlik etmektedir. Model olma; günlük planda yer alan stratejiyi, annenin daha iyi anlamasını sağlamak amaçlı uygulamacı sergilemektedir. Uygulamacı serbest oyun etkinliklerinde çocukla etkileşimde bulunarak anneye model olmuştur. Rehberlik etme sürecinde ise, uygulamacının yaptığı örnek uygulamaya benzer bir uygulamayı annenin gerçekleştirmesi istenmiştir. Annenin çocuğuyla gerçekleştirdiği öğretim oturumu esnasında, karşılaştığı sorunları ya da stratejiyi eksik uygulaması durumunda uygulamacı anneye rehberlik etmiştir.

\section{Ev Ödevinin Hazırlanması}

Uygulamacı ve anne-çocuk ile gerçekleştirilen öğretim oturumunda model olunan ve rehberlik edilen stratejilerin, annenin çocuğu ile zaman geçirdiği ortam ve zamanlarda bu stratejileri nasıl gerçekleştireceğine ilişkin Ev Ödevi Planı (EÖP) hazırlanmıştır. Bu süreçte, uygulamacı anne ile birlikte bu öğretim oturumunu günlük rutinlerde nasıl uygulayabileceklerine karar vermişlerdir. Annenin bu EÖP'yi bir sonraki öğretim oturumuna kadar hergün fırsat yaratabildiği her an uygulaması istenmiştir. Bir sonraki öğretim oturumunda, anne ile birlikte bir önceki uygulama oturumuna ilişsin değerlendirme yapılmış ve ortaya çıkmış ya da çıkacak olası problemlerin bir daha yaşanmaması için annelere rehber olunmuştur. Aşağıdaki Tablo 1'de katılımcılara toplam uygulanan öğretimsel strateji, bilgi notlarının sayıları ve uygulama süresi yer almaktadır.

Tablo 1. Katılımcılara uygulanan ETEÇOM ögretimsel stratejileri, ETEÇOM bilgi notları toplam sayılarl ve toplam uygulama süresi

\begin{tabular}{ll|lll}
\hline $\begin{array}{l}\text { ETEÇOM } \\
\text { Uygulaması }\end{array}$ & Programı & 1.Katılımc1 & 2.Kat1lımc1 & 3.Katılımc1 \\
\hline
\end{tabular}




\begin{tabular}{l|lll}
\hline Etkileşimsel Strateji & 40 & 39 & 40 \\
Bilgi Notu & 34 & 36 & 36 \\
Uygulama Süresi & 14 hafta & 13 hafta & 12 hafta \\
\hline
\end{tabular}

ETEÇOM Programı'nın aşamaları ve öğretim oturumları sırasında, uygulamacı oturumlarında çocuğun ve ailenin bireysel özelliklerine uygun olarak stratejiler seçebilmektedir (Mahoney ve MacDonald, 2007). Dolayısıyla program, çocuk ve ailelerin bireysel özellikleri ve gereksinimlerine göre plan yapmaya izin veren yapıda esnek bir programdır (Mahoney ve MacDonald, 2007). ETEÇOM Programı'nın standart uygulama basamaklarının yanı sıra bu araştırmada, katılımcıların özelliklerine göre ve ETEÇOM Programı'nın esnek yapısına bağglı olarak araştırmacı bazı uyarlamalar yapmıştır. Günlük planın hazırlanması, günlük planın anneye açıklanması ve ev ödevlerinin verilmesi aşamalarında programın standart yapısı korunmuş bilgi notlarının ve stratejilerin sunulması aşamalarında araştırmacı bazı uyarlamalara yer vermiştir. Stratejilerin sunulması aşamasında, ETEÇOM temel davranış seçici ve ETEÇOM temel davranış profili kullanılmamıştır. Araştırmanın temel amacının OSB'li çocukların sosyal etkileşim becerilerini desteklemek olması bağlamında her katılımcı anneçocuk çiftinin bireysel farklılıkları ve gereksinimlerine bağlı olarak seçimler yapılmıştır. Aynı zamanda stratejiler ailelere gösterildikçe yeni bir stratejiye geçildiği zaman annelerin ve çocukların tam olarak stratejiyi benimseyip uygulayabilmesi için uygulama aşamasında aralarda o zamana kadar verilen tüm stratejilerin ve bilgi notlarının tekrarı niteliğinde genel tekrarlara da yer verilmiştir. Tablo 2,3,4'de çocukların deney sürecinde, oturumlar, oturumlarda yer verilen öğretimsel strateji, bilgi notu sayıları, oturumlarda yer verilen temel davranışlar ve hangi gelişim alanını içerdiği bilgisine yer verilmektedir.

Tablo 2. Birinci katılımcı çocuğa uygulanan yanıtlayıcı etkileşim strateji sayısı/gelişim alanları

\begin{tabular}{|c|c|c|c|c|}
\hline \multicolumn{5}{|c|}{ Birinci Katılımc1 } \\
\hline Oturum & $\begin{array}{l}\text { Yanıtlayıcı } \\
\text { Etkileşim } \\
\text { Strateji } \\
\text { Sayısı }\end{array}$ & $\begin{array}{l}\text { Bilgi Notu } \\
\text { Sayis1 }\end{array}$ & $\begin{array}{l}\text { Temel } \\
\text { Davranış }\end{array}$ & $\begin{array}{l}\text { Gelişim } \\
\text { Alanı }\end{array}$ \\
\hline 1 & 2 & 2 & Sosyal Oyun & Bilişsel \\
\hline 2 & 2 & 1 & Sosyal Oyun & Bilişsel \\
\hline 3 & 2 & 2 & Sosyal Oyun & Bilişsel \\
\hline \multicolumn{5}{|c|}{ Genel Tekrar } \\
\hline 5 & 2 & 2 & Etkileşim Başlatma & Bilişsel \\
\hline 6 & 2 & 1 & Ortak Dikkat & İletişim \\
\hline 7 & 1 & 1 & Araştırma & Bilişsel \\
\hline 8 & 2 & 1 & Pratik Yapmak & Bilișsel \\
\hline 9 & 2 & 1 & Pratik Yapmak & Bilişsel \\
\hline
\end{tabular}




\begin{tabular}{|c|c|c|c|c|}
\hline \multicolumn{5}{|c|}{ Genel Tekrar } \\
\hline 11 & 2 & 2 & Problem Cözme & Bilișsel \\
\hline 12 & 1 & 1 & Amaçlı İletişim & İletişim \\
\hline 13 & 2 & 2 & İşbirliği Yapma & Sosyal-Duygusal \\
\hline 14 & 2 & 2 & Güven & Sosyal-Duygusal \\
\hline 15 & 2 & 2 & $\begin{array}{l}\text { Karş111kli } \\
\text { Konuşma/Sohbet }\end{array}$ & İletişim \\
\hline 16 & 2 & 1 & Kendine Güven & Sosyal-Duygusal \\
\hline 17 & 1 & 1 & $\begin{array}{l}\text { Karş111klı } \\
\text { Konuşma/Sohbet }\end{array}$ & İletişim \\
\hline 18 & 1 & 1 & Ortak Dikkat & İletişim \\
\hline 19 & 2 & 2 & Etkinliğe Katılım & İletişim \\
\hline 20 & 2 & 2 & Kendine Güven & Sosyal-Duygusal \\
\hline 21 & 2 & 2 & Ortak Etkinlik & İletişim \\
\hline 22 & 2 & 2 & Empati Kurma & Sosyal Duygusal \\
\hline 23 & 2 & 2 & İşbirliği Yapma & Sosyal Duygusal \\
\hline 24 & 2 & 1 & Kontrol Etme & Sosyal Duygusal \\
\hline
\end{tabular}

Tablo 3. İkinci katılımcı çocuğa uygulanan yanıtlayıcı etkileşim strateji sayısı/gelişim alanları

\begin{tabular}{|c|c|c|c|c|}
\hline \multicolumn{5}{|c|}{ İkinci Katılımc1 } \\
\hline \multirow[t]{4}{*}{ Oturum } & Yanitlayıc1 & Bilgi Notu & Temel & Gelișim \\
\hline & Etkileşim & Say1S1 & Davranış & Alanı \\
\hline & Strateji & & & \\
\hline & Say1s1 & & & \\
\hline 1 & 2 & 2 & Sosyal Oyun & Bilişsel \\
\hline 2 & 2 & 1 & Sosyal Oyun & Bilișsel \\
\hline 3 & 1 & 2 & Sosyal Oyun & Bilișsel \\
\hline \multirow[t]{2}{*}{4} & 2 & 2 & Etkileșim & Bilișsel \\
\hline & & & Bașlatma & \\
\hline \multirow[t]{2}{*}{5} & 2 & 2 & Etkileșim & Bilișsel \\
\hline & & & Bașlatma & \\
\hline 6 & \multicolumn{2}{|c|}{ Genel Tekrar } & & \\
\hline 7 & 1 & 1 & Etkinliğe Katılım & İletişim \\
\hline 8 & 2 & 1 & Pratik Yapmak & Bilișsel \\
\hline 9 & 2 & 2 & Problem Çözme & Bilișsel \\
\hline 10 & 1 & 1 & Ortak Dikkat & İletişim \\
\hline 11 & 1 & 1 & Ortak Etkinlik & İletişim \\
\hline \multirow[t]{2}{*}{12} & 2 & 2 & Güven & Sosyal- \\
\hline & & & & Duygusal \\
\hline \multirow[t]{2}{*}{13} & 2 & 2 & Karş1l1klı & İletişim \\
\hline & & & Konuşma/ Sohbet & \\
\hline \multirow[t]{2}{*}{14} & 2 & 1 & Karşıl1klı & İletişim \\
\hline & & & Konuşma/ Sohbet & \\
\hline 15 & 2 & 2 & Amaçlı İletişim & İletişim \\
\hline 16 & 2 & 1 & Amaçlı İletişim & İletisim \\
\hline 17 & 2 & 2 & Seslendirme & İletisim \\
\hline 18 & 2 & 2 & Keșif & Bilissel \\
\hline 19 & \multicolumn{2}{|c|}{ Genel Tekrar } & & \\
\hline \multirow[t]{2}{*}{20} & 2 & 2 & Empati Kurma & Sosyal \\
\hline & & & & Duygusal \\
\hline \multirow[t]{2}{*}{21} & 2 & 2 & İşbirliği Yapma & Sosyal \\
\hline & & & & Duygusal \\
\hline \multirow[t]{2}{*}{22} & 2 & 2 & Seslendirme & İletişim \\
\hline & Erken Çocuklı & $\begin{array}{l}\text { r1 Dergisi } \\
\text { 3. Ekim }\end{array}$ & $\begin{array}{l}\text { lof Early Childhood Studie } \\
2 \cdot \text { Issue } 3 \cdot \text { October }\end{array}$ & \\
\hline
\end{tabular}




\begin{tabular}{lllll}
23 & 2 & 2 & Kontrol Etme & $\begin{array}{l}\text { Sosyal } \\
\text { Duygusal } \\
\text { İletişim }\end{array}$ \\
\hline
\end{tabular}

Tablo 4. Üçüncü katılımcı çocuğa uygulanan yanıtlayıcı etkileşim strateji sayısı/gelişsim alanları

\begin{tabular}{|c|c|c|c|c|}
\hline \multicolumn{5}{|c|}{ Üçüncü Kat1lımc1 } \\
\hline Oturum & $\begin{array}{l}\text { Yanıtlayıc1 } \\
\text { Etkileşim } \\
\text { Strateji } \\
\text { Sayısı }\end{array}$ & Bilgi Notu Sayıs1 & Temel Davranış & Gelişim Alanı \\
\hline 1 & 2 & 2 & Sosyal Oyun & Bilişsel \\
\hline 2 & 2 & 1 & Sosyal Oyun & Bilişsel \\
\hline 3 & 1 & 1 & Sosyal Oyun & Bilişsel \\
\hline 4 & 2 & 2 & $\begin{array}{l}\text { Etkileşim } \\
\text { Başlatma }\end{array}$ & Bilişsel \\
\hline 5 & Ger & & & \\
\hline 6 & 1 & 1 & Pratik Yapmak & Bilişsel \\
\hline 7 & 2 & 2 & Güven & Sosyal-Duygusal \\
\hline 8 & 2 & 2 & Ortak Dikkat & İletişim \\
\hline 9 & 2 & 2 & Problem Çözme & Bilişsel \\
\hline 10 & 2 & 2 & Etkinliğe Katılım & İletişim \\
\hline 11 & 2 & 2 & Amaçlı İletişim & İletişim \\
\hline 12 & 1 & 1 & Amaçli İletişim & İletişim \\
\hline 13 & 2 & 2 & $\begin{array}{l}\text { Etkileşim } \\
\text { Başlatma }\end{array}$ & Bilişsel \\
\hline 14 & 2 & 2 & $\begin{array}{l}\text { Karş1liklı } \\
\text { Konuşma/Sohbet }\end{array}$ & İletişim \\
\hline 15 & 2 & 1 & Ortak Dikkat & İletişim \\
\hline 16 & 2 & 2 & İşbirliği Yapma & Sosyal-Duygusal \\
\hline 17 & 2 & 2 & Seslendirme & İletişim \\
\hline 18 & & & & \\
\hline 19 & 2 & 2 & Araştırma & Bilişsel \\
\hline 20 & 2 & 1 & Güven & Sosyal-Duygusal \\
\hline 21 & 2 & 1 & İşbirliği Yapma & Sosyal-Duygusal \\
\hline 22 & 1 & 1 & Ortak Dikkat & İletişim \\
\hline 23 & 2 & 2 & Empati Kurma & Sosyal-Duygusal \\
\hline 24 & 2 & 2 & Kontrol Etme & Sosyal-Duygusal \\
\hline
\end{tabular}

\section{ETEÇOM Sonu Değerlendirme}

Araştırmada ETEÇOM uygulanması bittikten sonra her bir çocuk için, çocukların sosyal etkileşim becerileri düzeylerini belirlemek için öğretim sonu değerlendirmesi yapılmıştır. Anne çocuk ikilisinden, gelişimsel dönemlerine uygun olarak düzenlenmiş oyuncaklarla 10 ile 20 dakika süresince oyun oynamaları istenmiş ve oyun video kaydına alınmıştır.

\section{İzleme}


Araştırmada ETEÇOM uygulanması bittikten iki ay sonra her bir çocuk için, çocukların sosyal etkileşim becerileri düzeylerini belirlemek için anne ve çocuk çiftlerine izleme değerlendirmesine yer verilmiştir. İzleme değerlendirmesi öğretim öncesinde olduğu gibi anne ve çocuğun kendi evlerinde beş gün süresince 10-20 dakikalık oyun etkinliği gerçekleştirmeleri istenmiş ve kamera kaydı alınarak toplanmıştır.

\section{Verilerin Toplanması ve Kodlanması}

Araştırmada verilerin toplanılmasında, uygulanan programın OSB'li çocukların sosyal etkileşim becerileri üzerindeki etkisi gözlem verilerinin toplanması ve kodlanmasına yer verilerek gerçekleştirilmiştir.

$\mathrm{Bu}$ araştırmanın bağımlı değişkeni olan OSB'li çocukların sosyal etkileşim becerilerinin tanımlanmasında alan yazının incelenmesi sonucunda bu araştırmada, OSB'li çocukların sosyal etkileşim becerileri üç alt kategoride gözlemlenmiştir. 1) Etkileşimi başlatma, 2) Etkileşime yanıt verme, 3) Etkileşimi sürdürme davranışlardır. Çocukların sosyal etkileşim becerilerine yönelik veriler, video yoklamalarının analiz edilmesi yoluyla ölçülmüştür. Haftada iki gün 10'ar dakika araştırmacı tarafından, çocukların anneleri ile sosyal etkileşim becerileri kaydedilmiştir. Çocukların sosyal etkileşim becerileri arttırılmak istenen bir davranış olduğu için, eğitim oturumları boyunca çocukların davranışları kısmi aralık kaydı kullanılarak kaydedilmiştir. Kısmi aralık kaydında, 10 dakikalık gözlem süresi, 10 saniyelik zaman aralıklarına bölünmüş, gözlem yapılacak davranışın bu zaman aralığı içinde var olup olmamasına bakılmıştır. Gözlemlenen davranış bölünmüş olan 10 saniyelik zaman aralıkları içinde davranışı gerçekleşirse (davranışı 10 saniyelik zaman aralığı içinde bir defa sergilediğinde de) "+" gerçekleşmezse (10 saniyelik zaman aralığı içinde hiç bir şekilde davranışı sergilemezse) "-" olarak kabul edilmiştir. Çocukların sosyal etkileşim beceri yüzdesini hesaplarken; Davranışın oluştuğu aralık sayısı/Toplam aralık sayısı X 100 formülü kullanılmıştır.

ETEÇOM' un katılımcı çocukların sosyal etkileşim becerilerinin iki alt kategorisi olan etkileşimi başlatma ve etkileşimi sürdürme davranışlarına etkisinin olup olmadığını, eğer etkisi varsa sıklığı ve süresine dair daha detaylı bilgi toplayabilmek adına her bir çocuk katılımcının başlama düzeyi evresi, uygulama evresi ve izleme evrelerinden üçer oturum kodlamaya dahil edilerek, katılımcı çocukların etkileşimi başlatmanın sayılarına ve etkileşimi sürdürme sürelerine de bakılmıştır.

\section{Sosyal Etkileşimi Başlatma}


Etkileşim başlatma, çocuğun annesine yönelttiği, sesli/sözlü veya jest/mimik davranışlarını içermektedir. Selamlaşma, paylaşma, yardım etme, dokunma, yorum yapma, annesinin adını söyleme, yönerge verme ve sosyal etkileşime yönelik diğer olumlu davranışları içeren ve de sosyal bir yanıt alabilmek amacıyla doğrudan anneye yöneltilmiş herhangi bir motor ya da sesli davranışlar puanlanmaktadır. Verilerin puanlanması sırasında çocukların (etkileşim başlatmaları) sayılabilir davranışları için olay kaydı kullanılmıştır. Sayılabilir davranış başlangıcı ve bitişi olan, birbirinden ayrılan ve kolayca tanımlanabilen davranışlardır (Özyürek, 2011). Sayılabilir davranışlar için en uygun kayıt yöntemi olay kaydıdır. Sayılabilir bir davranışın belirli bir zaman aralığında kaç kere meydana geldiğini belirlemek için olay kaydı kullanılır. Olay kaydı yaparken hedeflenen davranış her gerçekleştiğinde işaret konulmalıdır. $\mathrm{Bu}$ araştırmada da 10 dakikalık süre içerisinde çocukların kaç kere etkileşim başlattıkları sayılmıştır. Kodlama dışında bırakılan süre toplam uygulama süresinden çıkarılarak ortalamalar belirlenmiştir (örneğin, 10 dakikalık uygulama sırasında 1 dakikalık kodlanamayan süre varsa davranışın ortalaması 9 dakika üzerinden hesaplanmıştır).

\section{Sosyal Etkileşimi Sürdürme}

Başlatmalara ve annenin etkileşim yanıtlarına cevap verildiği ya da etkileşimin cevap sonrasında da devam ettiği durumlarda puanlanmaktadır. Sözel-sözel olmayan etkileşimde, anneye tepki olarak ya da kendi başlattığı etkinliği sürdürmek amacıyla sözel/sözel olmayan davranışlar sergilendiği zaman puanlanmaktadır. Verilerin puanlanması sırasında çocukların (etkileşim sürdürme) sürekli davranışları için süre kaydı kullanılmıştır. Çünkü çocukların etkileşim sürdürme davranışlarının ne kadar süreyle devam ettiğini belirlemek istediğimizden ve sürekli bir davranış olduğu için süre kaydına yer verilmiştir. Süre kaydından tüm süre kaydı kullanılmıştır. Tüm süre kaydında gözlem dönemi süresince çocuğun göstermiş olduğu davranışın toplam süresi ölçülür. Bir davranışı kodlarken davranışın başladığı zaman kodlama kağıdında birinci sütunda not edilerek aynı şekilde davranışın bittiği zamanda dakika, saniye ve bir saniyenin onda birini içerecek şekilde (5:48:09 gibi) kodlama kağıdına not edilmiştir. Çocukların sosyal etkileşim sürdürme süresi hesaplanırken; Davranışın görüldüğü toplam süre/ davranışın kayıt edildiği toplam süre X 100 formülü kullanılmıştır.

\section{Uygulama Güvenirliği}

$\mathrm{Bu}$ araştırmada ETEÇOM’un uygulama oturumlarının araştırmacı tarafından doğru şekilde uygulanıp uygulanmadığını belirlemek üzere uygulama güvenirliği verileri toplanmıştır. Uygulama güvenirliği verilerinin değerlendirilmesi amacıyla araştırma kapsamında uygulama güvenirliği formu geliştirilmiştir. Bu form oluşturulurken planlarda bilgilendirme oturumu için 
nelerin yapılacağı, olumlu ilişkilerin oluşturulması ve oturumların gözden geçirilmesi, amaç ve gerekçe, öğretim stratejilerin gösterilmesi ve uygulanması ve aile eylem planı yer almaktadır. Araştırmacı her oturumda izleyeceği adımları kontrol listesi haline getirerek oturum sırasında kontrol listesine bakarak kendisine rehber olarak kullanmış ve oturum sonunda aşamalara uygun olarak uygulama yapıp yapmadığını kontrol etmiştir. Araştırmacı tarafından hazırlanan kontrol listesi uygulama güvenirliği formu olarak kullanılmıştır. Anne-çocuk ikilisi ile yapılan uygulama oturumlarının videoları Gazi Üniversitesi Özel Eğitim Bölümü Görme Engellilerin Eğitimi Anabilim Dalı'nda araştırma görevlisi olan aynı zamanda doktora eğitimini alan ikinci bir gözlemciye verilerek izlemesi ve uygulama basamaklarını işaretlemesi istenmiştir. Başlama düzeyi oturumları, öğretim uygulama oturumları, öğretim sonu değerlendirme ve izleme oturumlarının her birinden örnekler içerecek şekilde tüm uygulamaların en az \%30'unu karşılayacak sayıda (30) videolar ve kayıt formları verilerek bu kayıt formlarını kendisine verilen videoları izleyerek doldurması istenmiştir. Gözlemcinin formları doldurulduktan sonra veriler; Gözlenen araştırmacı davranış1/ Planlanan araştırmacı davranışı X100 formülü kullanılarak hesaplanmıştır (Billingsley, White ve Munson, 1980). Bu araştırmada her aşama için uygulama güvenirliği \% 100 çıkmıştır.

\section{Gözlemciler Arası Güvenirliğin Hesaplanması}

Doğrudan çocukların sosyal etkileşim becerilerini ölçümlemeye dayalı verilerle ilgili gözlemciler arası güvenirlik verileri belirlenmiştir. Bu araştırmada araştırmaya katılan üç çocuk için toplam 107 oturum gözlem verisi toplanmıştır. Elde edilen verilerin \%30’u seçkisiz atama ile seçilerek Gazi Üniversitesi Özel Eğitim Bölümü’nde doktora eğitimi alan bir uzman olan ikinci bir gözlemci tarafından kodlanmıştır. Birinci çocuk için, yapılan gözlem verilerinden seçkisiz atama ile belirlenen; bir tane başlama düzeyi gözlem verisi, yedi tane uygulama gözlem verisi, iki tane izleme gözlem verisi, ikinci çocuk için; iki tane başlama düzeyi gözlem verisi, yedi tane uygulama gözlem verisi, iki tane izleme gözlem verisi, üçüncü çocuk için; üç tane başlama düzeyi gözlem verisi, yedi tane uygulama gözlem verisi, iki tane izleme gözlem verisi olmak üzere üç çocuk için toplam otuzüç tane gözlem verisi ikinci gözlemciye verilmiştir. İkinci gözlemci tarafından otuzüç gözlem verisi izlenerek, kısmi aralık kayıt formuna kodlanmıştır. Gözlemciler arası güvenilirlik; Görüş birliği/ Görüş birliği +Görüş ayrılığ X 100 formülü kullanılarak hesaplanmıştır (İftar ve Tekin, 1997). Birinci çocuğun seçkisiz atama ile seçilmiş 10 tane gözlem verisi için en az \%81 en fazla \%85 olmak üzere ortalama \%83 ikinci çocuğun seçkisiz atama ile seçilmiş 11 tane gözlem verisi için en az \%83 en fazla \%92 olmak üzere ortalama \% 87,5 üçüncü çocuğun seçkisiz atama ile seçilmiş 12 tane gözlem verisi için 
en az \%84 en fazla \%92 olmak üzere ortalama \%88 düzeyinde gözlemciler arası güvenilirlik bulunmuştur. Seçkisiz atama ile \%30’u seçilen tüm verilerin, gözlemciler arası güvenilirliği ortalama \% 86 düzeyinde hesaplanmıştır.

\section{Verilerin Analizi}

Tek denekli deneysel desenler ile yapılan araştırmalarda verilerin analizi, sonuçların grafikte gösterilip, grafiğin görsel olarak yorumlanması yoluyla yapılır (Tawney ve Gast, 1984). Bu araştırmada, tek denekli desenlerinden denekler arası çoklu başlama deseni kullanılarak grafikle gösterilen verilerin görsel olarak analizi yapılmıştır.

Çocukların sosyal etkileşim becerilerinin analizinde uygulama öncesi, sırası ve sonrası gözlem verileri, çoklu başlama desenine uygun çizgi grafiği ile gösterilmiştir. ETEÇOM' un çocukların sosyal etkileşim becerilerine etkisinin olup olmadığını, eğer etkisi varsa sıklığı ve süresine dairde bilgi toplayabilmek için her bir çocuk katılımcının başlama düzeyi evresi, uygulama evresi ve izleme evrelerinden üçer oturum kodlamaya dahil edilerek etkileşimi başlatmanın sayısına ve etkileşimi sürdürmenin süresine bakılmış olan gözlemsel veriler sütün grafiğinde gösterilmiştir

\section{BULGULAR}

Araştırmada ETEÇOM Programı'nın, OSB'li çocukların sosyal etkileşim becerilerine (etkileşim başlatma, etkileşime yanıt verme, etkileşimi sürdürme) yönelik bir etkisinin olup olmadığını saptama amaçlanmıştır. Bu amaca yönelik olarak her bir çocuğun sosyal etkileşim becerilerinin bulguları Grafik 1'de gösterilmiştir. Aşağıdaki Tablo 5'de üç katılımcı çocuğun, başlama, uygulama ve izleme evrelerindeki sosyal etkileşim beceri yüzdeleri, etkileşim başlatma sayıları ve etkileşim sürdürme yüzde/süresi yer almaktadır.

Tablo 5. Üç katılımcı çocuğun başlama, uygulama ve izleme evrelerindeki sosyal etkileşim beceri yüzdeleri, etkileşim başlatma sayıları ve etkileşim sürdürme yüzde/süresi

\begin{tabular}{|c|c|c|c|c|}
\hline Kat1lımc1 & Davranış & $\begin{array}{l}\text { Başlama } \\
\text { Düzeyi Evresi }\end{array}$ & $\begin{array}{l}\text { Uygulama } \\
\text { Evresi }\end{array}$ & $\begin{array}{l}\text { İzleme } \\
\text { Evresi }\end{array}$ \\
\hline \multirow{5}{*}{ 1.Çocuk } & $\begin{array}{l}\text { Sosyal etkileşim } \\
\text { becerisinin yüzdeliği }\end{array}$ & $\% 31$ & $\% 85$ & $\% 87$ \\
\hline & $\begin{array}{l}\text { Etkileşim başlatma } \\
\text { sayısı ortalaması }\end{array}$ & 4 & 8 & 8 \\
\hline & $\begin{array}{l}\text { Etkileşim sürdürme } \\
\text { süresi }\end{array}$ & $3.1 \mathrm{dk}$ & $8.4 \mathrm{dk}$ & $8.1 \mathrm{dk}$ \\
\hline & $\begin{array}{l}\text { Etkileşim } \\
\text { yüzdesi }\end{array}$ & $\% 31$ & $\% 84$ & $\% 83$ \\
\hline & $\begin{array}{l}\text { Sosyal etkileşim } \\
\text { becerisinin yüzdeliği }\end{array}$ & $\% 10$ & $\% 73$ & $\% 78$ \\
\hline
\end{tabular}




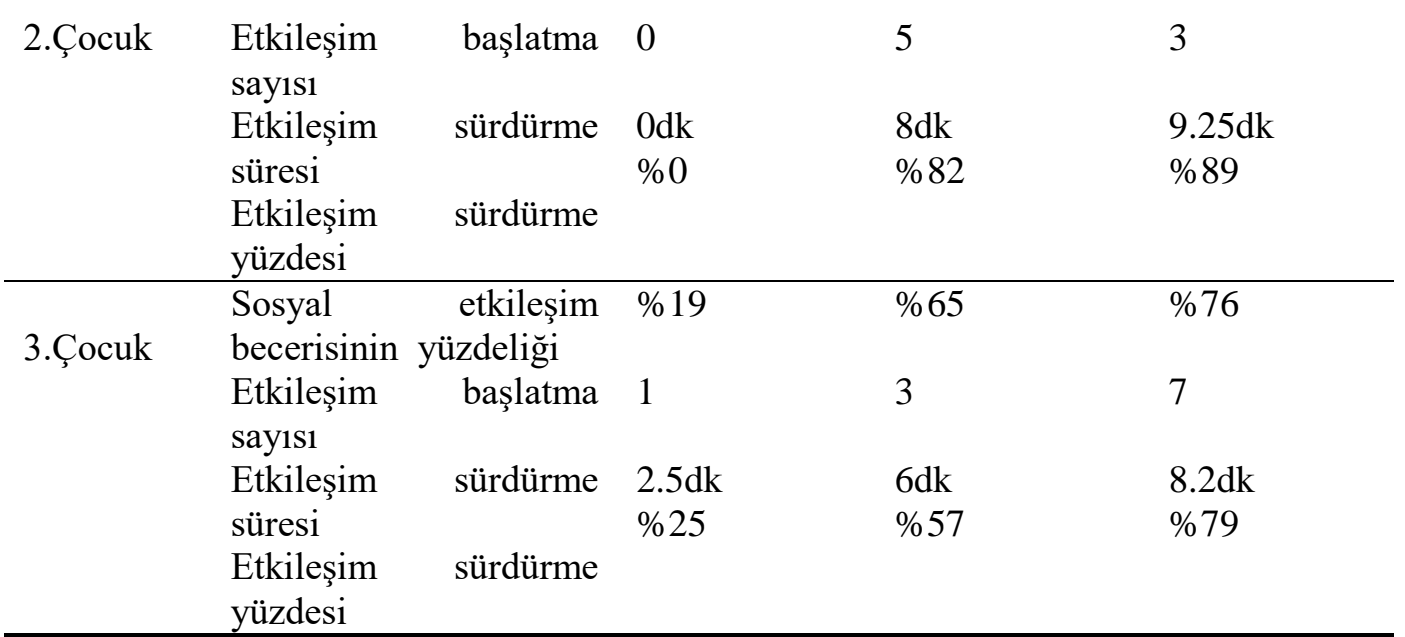

\section{Birinci Katılımcının Sosyal Etkileşim Becerilerinin Gözlem Verileri Bulguları}

Birinci katılımcının sosyal etkileşim becerilerinin kaydedildiği ETEÇOM Programı'nın uygulanmasının öncesi başlama düzeyi evresi verileri üç gün süre ile toplanmıştır. Başlama düzeyi evresinde birinci katılımcının annesiyle serbest oyun ortamında sergilediği sosyal etkileşim beceri yüzdesi 27 ila 40 arasında değişmiş olup, sosyal etkileşim beceri ortalaması $\% 31$ düzeyindedir.

Tablo 5'de görüldüğü gibi birinci katılımcının serbest oyun ortamı içerisinde annesine yönelik etkileşim başlatma düzeyi ortalama sayısı 4'tür. Başlama düzeyi evresi oturumunda annesiyle etkileşim sürdürme davranışının yüzdesi ise \%31'dir. Grafik 1'de görüldüğü gibi birinci katılımcı çocuğun serbest oyun bağlamı içerisinde annesiyle girdiği sosyal etkileşim becerisinin düşük düzeyde olduğu görülmüştür.

Birinci katılımcının ETEÇOM Programı uygulanmaya başlanıldığında ilk oturumdan itibaren sosyal etkileşim becerilerinin arttığı gözlenmiştir. Başlama düzeyi evresinin son oturumunda birinci katılımcının sergilediği sosyal etkileşim becerilerinin yüzdesi \%27 iken uygulama başladıktan sonra birinci oturumda $\% 77$, ikinci oturumda $\% 87$, üçüncü oturumda $\% 80$, beşinci oturumda \%90'a yükselmiştir. Uygulamanın 9. oturumunda birinci katılımcının sosyal etkileşim beceri yüzdesi \%57'lere düşmüş ancak sonraki oturumlarda yine yükselme görülmüştür. İlk oturumlarda ani bir yükseliş eğilimi yakalanırken uygulama süresince, 9.oturumda veri eğiminde ani düşüşler gözlemlenmiş ancak ani düşüşlerdeki ortalamanın başlama düzeyi evresinden $\% 30$ oranında farklılaştığı görülmüştür. Birinci katılımcının uygulama düzeyinde sosyal etkileşim beceri yüzde ortalaması \%85 düzeyindedir (en düşük $\% 57$ ile en yüksek \%97). 
$\mathrm{Bu}$ çalışmada davranışın sıklığına ya da süresine yönelik net bilgi elde edebilmek için çocukların sosyal etkileşim becerilerinin sıklığı ve süresine dair bilgi toplayabilmek adına her bir çocuk katılımcının başlama düzeyi evresi, uygulama evresi ve izleme evrelerinden üçer oturum kodlamaya dahil edilerek, katılımcı çocukların etkileşimi başlatmanın sayılarına ve etkileşimi sürdürme sürelerine de bakılmıştır. Tablo 5'de görüldüğü gibi birinci katılımcının etkileşim başlatma sayısı 4'ten 8'e yükselmiş, annesiyle girdiği sosyal oyun etkileşimi bağlamında etkileşimi sürdürme yüzdesi \%31'den \%84'e yükselmiştir. Grafik1, Grafik 2 ve 3'de görüldüğ̈̈ gibi birinci katılımcının uygulama oturumları sonrasında annesiyle girdiği sosyal etkileşimi başlatma, etkileşime yanıt verme ve etkileşimi sürdürme davranışlarında çok büyük bir oranla artışın olduğu gözlenmiştir (sosyal etkileşim becerilerinde ve etkileşim sürdürme davranışlarında ortalama 2,70 kat artış sergilenmiştir).

Birinci katılımcı ile uygulama bittikten iki ay sonra beş oturum izleme verisi toplanmıştır. Birinci katılımcının izleme süreci birinci oturum sosyal etkileşim veri düzeyinin, uygulama sürecindeki ilk oturumun verisiyle aynı düzeyde olduğu gözlenmekle birlikte (\%77), diğer dört oturumda bu oran yükselmiştir (\%87, \%93,\%93,\%87). Birinci katılımcının uygulama düzeyinde sosyal etkileşim beceri yüzdesi ortalama \%85 düzeyinde iken izleme sürecindeki sosyal etkileşim becerilerinin yüzdesi \%87 olarak gerçekleşmiştir (en düşük \%77 ile en yüksek \%93). İzleme sürecinde Birinci katılımcının etkileşim başlatma sayısı ortalaması 8, etkileşimi sürdürme yüzdesi ortalaması \%83'tür. Uygulama evresinde etkileşimi başlatma sayısının uygulama evresinden iki ay sonra yine aynı oranda devam ettiği, etkileşimi sürdürme yüzdelik oranında \%1'lik bir düşüşün olduğu gözlenmektedir. Grafik 1,2 ve 3'te görüldüğü gibi birinci katılımcı çocuğun uygulamadan iki sonra kazandığı sosyal etkileşim becerilerini artırarak koruduğu hatta sosyal etkileşim becerilerinin yüzdesinin uygulama oturumundan yüksek düzeyde olduğu dikkat çekicidir. 


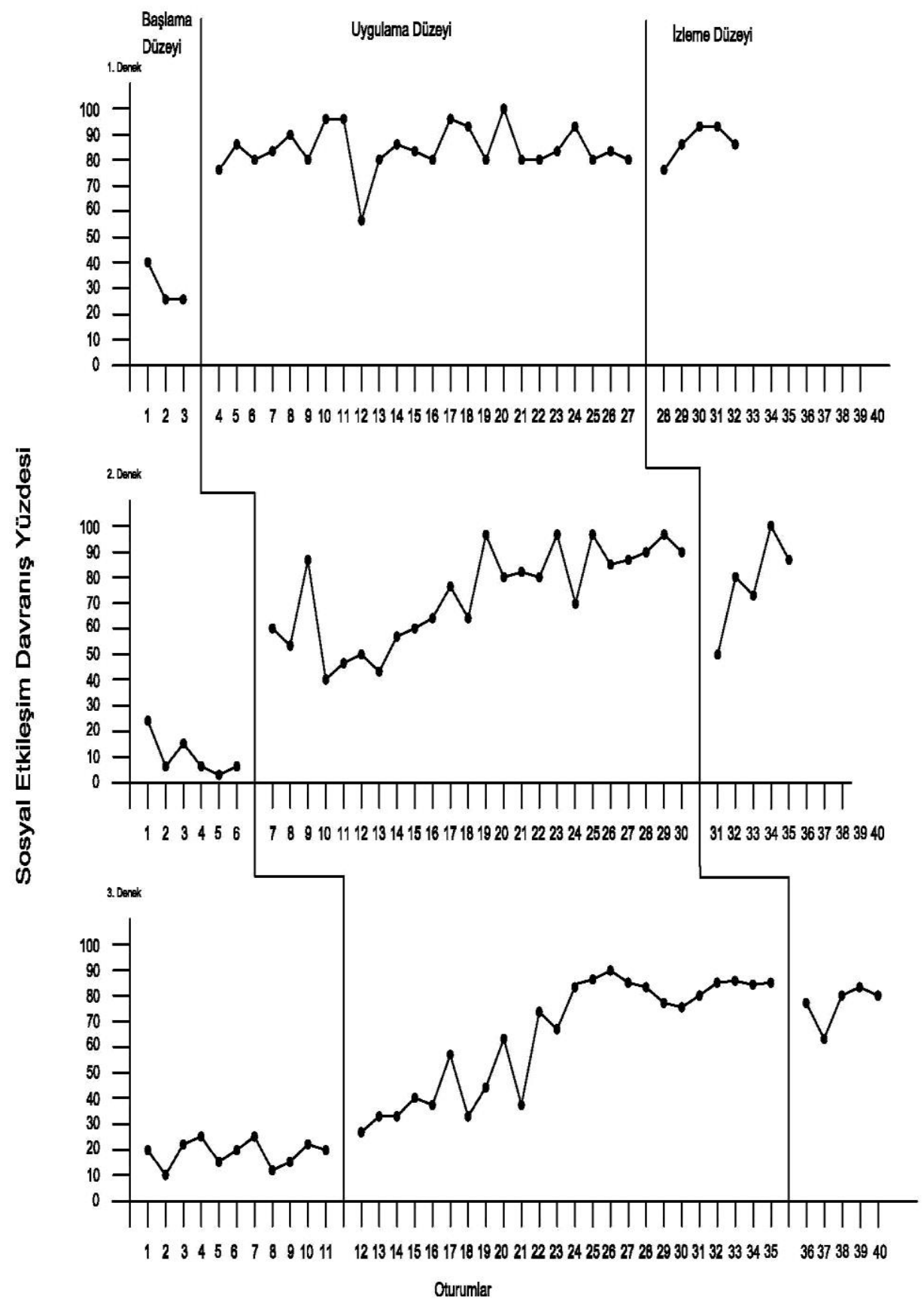

Grafik: Cocuk Katlimcların Sosyal Ekkileşim Davranıļan 


\section{İkinci Katılımcının Sosyal Etkileşim Becerilerinin Gözlem Verileri Bulguları}

İkinci katılımcının sosyal etkileşim becerilerinin kaydedildiği ETEÇOM Programı'nın uygulanmasının öncesi başlama düzeyi evresi verileri altı gün süre ile toplanmıştır. Başlama düzeyi evresinde ikinci katılımcının annesiyle serbest oyun ortamında sergilediği sosyal etkileşim beceri yüzdesi 3 ila 23 arasında değişmiş, sosyal etkileşim beceri ortalaması \%10 düzeyinde gerçekleşmiştir.

Tablo5'de görülebileceği gibi ikinci katılımcının serbest oyun ortamı içerisinde annesine yönelik etkileşim başlatmasının hiç olmadığı, başlama düzeyi evresi oturumunda annesiyle etkileşim sürdürme davranışının bulunmadığı görülmüştür. Grafik 1'de görüldüğü gibi ikinci katılımcı çocuğun serbest oyun bağlamı içerisinde annesiyle girdiği sosyal etkileşim becerisinin çok düşük düzeyde olduğu görülmüştür.

İkinci katılımıının ETEÇOM Programı uygulanmaya başlanıldığında ilk oturumdan itibaren sosyal etkileşim becerilerinin arttı̆̆ gözlenmiştir. Başlama düzeyi evresinin son oturumunda ikinci katılımcının sergilediği sosyal etkileşim becerilerinin yüzdesi \%7 iken uygulama başladıktan sonra birinci oturumda $\% 60$, ikinci oturumda $\% 53$, üçüncü oturumda $\% 86$ 'lara yükselmiştir. Uygulamanın 4. oturumunda ikinci katılımcının sosyal etkileşim beceri yüzdesi \%40'lara düşmüş sonraki oturumlarda yine yükselme görülmüştür. İlk oturumlarda ani bir yükseliş eğitimi yakalanırken uygulama süresince 4.oturumda veri eğiminde ani düşüşler gözlemlenmiş ancak ani düşüşlerdeki ortalamanın dahi başlama düzeyi evresinden \%30 oranında farklılaştığı görülmüştür. Tablo 5'de görüldüğü gibi İkinci katılımcının uygulama evresinde sosyal etkileşim beceri yüzdesi en düşük \%40 ile en yüksek \%97 sosyal etkileşim beceri yüzde ortalaması $\% 73$ düzeyindedir.

İkinci katılımcının etkileşim başlatma sayısı uygulamadan sonra 5'e yükselmiş, annesiyle girdiği sosyal oyun etkileşimi bağlamında etkileşimi sürdürme yüzdesi \%0'dan \%82'e yükselmiştir. Tablo 5 incelendiğinde ikinci katılımcının uygulama evresi oturumları sonrasında annesiyle girdiği sosyal etkileşimi başlatma, etkileşime yanıt verme ve etkileşimi sürdürme davranışlarında çok büyük bir oranla artışın olduğu gözlenmiştir (Grafik 2 ve 3 'te görüldüğü, sosyal etkileşim becerilerinde ortalama 7 kat, etkileşim sürdürme davranışında da ortalama 8 kat artış sergilenmiştir).

İkinci katılımcı ile uygulama bittikten iki ay sonra beş oturum izleme verisi toplanmıştır. İkinci katılımcının izleme süreci birinci oturumun veri düzeyinin, uygulama sürecindeki ilk oturumun verisinden daha düşük düzeyde olduğu gözlenmekle birlikte (\%50), diğer dört oturumda bu 
oran yükselmiştir (\%80,\%73,\%100,\%87). İkinci katılımcının uygulama evresinde sosyal etkileşim beceri yüzdesi ortalama \%73 düzeyinde iken izleme sürecindeki sosyal etkileşim becerilerinin yüzdesi \%78 olarak gerçekleşmiştir (en düşük \%50 ile en yüksek \%100). İzleme sürecinde ikinci katılımcının etkileşim başlatma sayısı 3, etkileşimi sürdürme yüzdesi \%89'dur. Uygulama evresinde etkileşimi başlatma sayısının uygulama evresinden iki ay sonra düşüş gösterdiği, etkileşimi sürdürme yüzdelik oranında \%7'lik bir artışın olduğu gözlenmektedir. İkinci katılımcı çocuğun uygulamadan iki ay sonra kazandığı sosyal etkileşim becerilerini yüksek oranda artırarak koruduğu hatta sosyal etkileşim becerilerinin ve annesiyle girdiği etkileşim bağlamında etkileşimi sürdürme yüzdesinin uygulama oturumundan yüksek düzeyde olduğu dikkat çekicidir.

\section{Üçüncü Katılımcının Sosyal Etkileşim Becerilerinin Gözlem Verileri Bulguları}

Üçüncü katılımcının sosyal etkileşim becerilerinin kaydedildiği ETEÇOM Programı'nın uygulanmasının öncesi başlama düzeyi evresi verileri 11gün süre ile toplanmıştır. Başlama düzeyi evresinde üçüncü katılımcının annesiyle serbest oyun ortamında sergilediği sosyal etkileşim beceri yüzdesi 10 ila 25 arasında değişmiş, sosyal etkileşim beceri ortalaması \%19 düzeyinde gerçekleşmiştir.

Tablo 5'de görülebileceği gibi üçüncü katılımcının serbest oyun ortamı içerisinde annesine yönelik etkileşim başlatma düzeyi ortalaması 1'dir. Başlama düzeyi evresi oturumunda annesiyle etkileşim sürdürme davranışının yüzdesi ise \%25'dir. Katılımcı çocuğun serbest oyun bağlamı içerisinde annesiyle girdiği sosyal etkileşim becerisinin birinci katılımcıdan düşük düzeyde, ikinci katılımcıdan biraz daha yüksek düzeyde ama genel olarak sosyal etkileşim becerilerinin oranının düşük olduğu görülmüştür.

Üçüncü katılımcının ETEÇOM Programı uygulanmaya başlanıldığında ilk oturumdan itibaren sosyal etkileşim becerilerinin arttığı gözlenmiştir. Ancak diğer iki katılımcıya oranla daha düşük oranda artış gerçekleşmiştir. Başlama düzeyi evresinin son oturumunda üçüncü katılımcının sergilediği sosyal etkileşim becerilerinin yüzdesi \%20 iken uygulama başladıktan sonra birinci oturumda $\% 27$, ikinci oturumda $\% 33$, üçüncü oturumda $\% 33$ düzeyindedir. 11. oturumdan itibaren sosyal etkileşim becerilerinin yüzdesi \%73'lere kadar yükselmiştir. Üçüncü katılımcının uygulama evresinde sosyal etkileşim beceri yüzdesi en düşük \%27 ile en yüksek $\% 90$ sosyal etkileşim beceri yüzde ortalaması \%65 düzeyindedir.

Üçüncü katılımcının uygulamadan sonra etkileşim başlatma sayısı 3'e yükselmiş, annesiyle girdiği sosyal oyun etkileşimi bağlamında etkileşimi sürdürme yüzdesi $\% 25$ 'ten \%57'ye 
yükselmiştir. Üçüncü katılımcının uygulama evresi oturumları sonrasında annesiyle girdiği sosyal etkileşimi başlatma, etkileşime yanıt verme ve etkileşimi sürdürme davranışlarında \%46'lık bir oranla artışın olduğu gözlenmiştir (sosyal etkileşim becerilerinde ortalama 3,4 kat, etkileşim sürdürme davranışında da ortalama 2,3 katlık artış).

Üçüncü katılımcı ile uygulama bittikten iki ay sonra beş oturum izleme verisi toplanmıştır. Üçüncü katılımcının izleme sürecinde sosyal etkileşim becerilerinde, etkileşim başlatma sayısında ve etkileşimi sürdürme yüzdeliklerinde hem kendi içinde uygulama evresindeki düzeyden hem de diğer iki katılımcıya oranla yüksek bir artış gerçekleşmiştir.

Üçüncü katılımcının uygulama evresinde sosyal etkileşim beceri yüzdesi ortalama \%65 düzeyinde iken izleme sürecindeki sosyal etkileşim becerilerinin yüzdesi \%76 olarak gerçekleşmiştir. İzleme sürecinde üçüncü katılımcının etkileşim başlatma sayısı 3 iken izleme evresinde bu oran 7'ye çıkmıştır. Etkileşimi sürdürme yüzdesi uygulama evresinde \%57 iken iki ay sonra alınan izleme evresinde \%79 düzeyindedir. Grafik 2 ve 3 'te görüldügü üçüncü katılımcı çocuğun uygulamadan iki ay sonra kazandığı sosyal etkileşim becerilerini yüksek oranda artırarak koruduğu hatta sosyal etkileşim becerilerinin ve annesiyle girdiği etkileşim bağlamında etkileşimi sürdürme ve etkileşim başlatma yüzdesinin uygulama oturumundan yüksek düzeyde olduğu dikkat çekicidir.

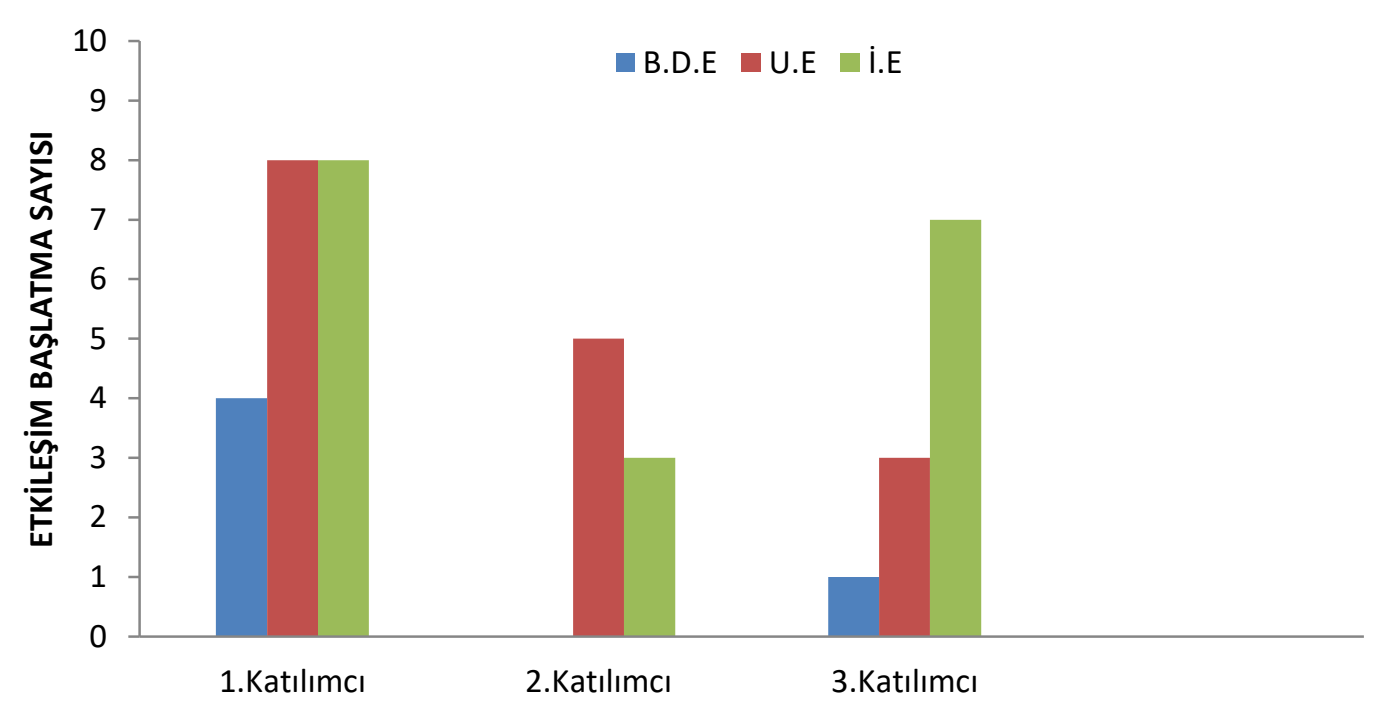

Grafik2: Çocuk katılımcıların, başlama düzeyi evresi, uygulama evresi, izleme evrelerinden alınan üç oturum etkileşim başlatma oranları (B.D.E: Başlama Düzeyi Evresi, U.E:Uygulama Evresi, İ.E: İzleme Evresi) 


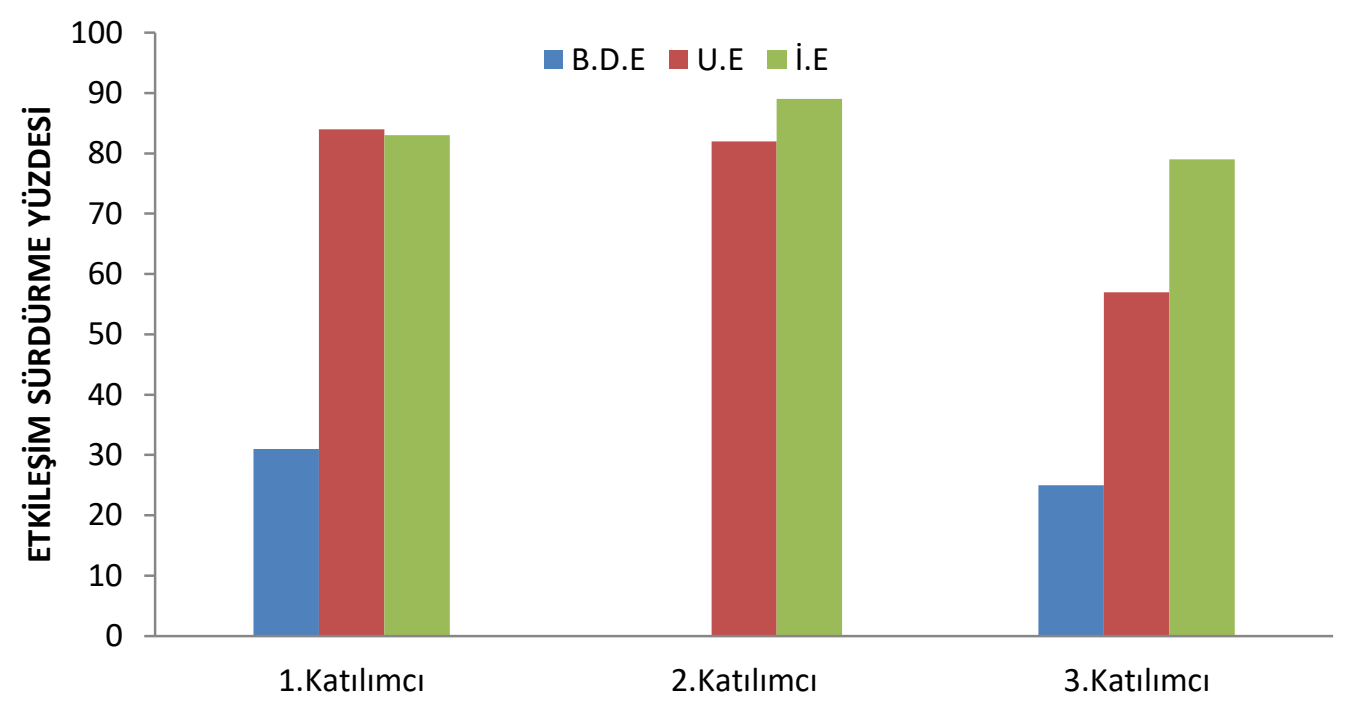

Grafik3: Çocuk katılımcıların, başlama düzeyi evresi, uygulama evresi, izleme evrelerinden alınan üç oturum etkileşimi sürdürme yüzdelik oranları (B.D.E: Başlama Düzeyi Evresi, U.E:Uygulama Evresi, I.E: İzleme Evresi)

\section{TARTIŞMA ve SONUÇ}

Bu araştırmada, ETEÇOM Programı'nın, OSB'li çocukların sosyal etkileşim becerileri üzerine etkililiği incelenmiştir $\mathrm{Bu}$ amaçla tek denekli deneysel desenlerden denekler arası çoklu başlama düzeyi deseni uygulanarak, ETEÇOM Programı'nın çocuk katılımcıların sosyal etkileşim becerilerine etkisi, uygulama öncesi, sırası ve sonrası gözlemsel veriler yoluyla toplanmıştır. Araştırma sonunda, çocukların sosyal etkileşim becerilerinde olumlu ilerlemeler gösterdikleri belirlenmiştir.

Araştırmanın sonunda her bir katılımcı çocuğun sosyal etkileşim becerilerinde yüksek düzeyde artış olduğu gözlenmiştir. Başlama düzeyinde üç katılımcı çocuğun annesiyle serbest oyun ortamında sergilediği sosyal etkileşim becerisi, annesine yönelik etkileşimi başlatma düzeyi, yanıt verme ve annesiyle etkileşim sürdürme davranışları düşük düzeyde iken; ETEÇOM Programı uygulandıktan sonra annesiyle girdiği sosyal etkileşimi başlatma, etkileşime yanıt verme ve etkileşimi sürdürme davranışlarında büyük oranda artışın olduğu belirlenmiştir.

Araştırmanın sonunda, katılımcıların sosyal etkileşim becerilerinde meydana gelen değişime bakıldığı zaman ikinci ve üçüncü katılımc1 çocuklar birinci katılımc1 çocuğa göre, sosyal etkileşim becerilerini çok daha yüksek oranda artırmışlardır. İkinci katılımcı çocuk başlama düzeyinde hiç sosyal etkileşim becerisi sergilemez iken birinci katılımcı çocuk diğer iki çocuğa göre daha yüksek sosyal etkileşim becerileri sergilemiştir. Bu sonucun birçok sebebi olabilir. Birinci katılımcı çocuğun diğer iki çocuğa göre yaşının daha büyük olması sonucu etkilemiş 
olabilir. İkincisi, birinci katılımcı çocuğun annesi çocuğunun OSB tanısı alması ile birlikte çok daha fazla kaynaklara kendi imkanları ile ulaşmaya çalışmış, haftanın yedi günü çocuğunu çeşitli sosyal aktivitelere (duyu bütünleme, spor, müzik vb.) dahil etmek için çaba göstermiştir. Aynı zamanda birinci katılımcı annenin altı yıllık çocuğu ile olan geçmiş yaşantısında annenin belli davranış kalıplarının (aşırı yönlendirici, başarı odaklı olması ve çocuğu ile girdiği her türlü etkileşimde çocuğuna göre çok daha aktif, soru soran ve çocuğuna fazla firsat vermeyen, oyunları kendisi kuran ve oyuncakları kendisi seçen vb.) çok yerleşmiş olması da bu sonuçlar arasındaki farkı açıklayabilir. İkinci ve üçüncü katılımcı çocukların yaşlarının daha küçük olması ve ailelerin sadece tanı sonrası özel özel eğitim merkezlerinde çocuklarına eğitim aldırmaları, kendilerinin hiç bir şekilde aile eğitimi almamış olması, erken eğitimin önemini ortaya tekrar çıkaracak şekilde verilen eğitimden çok daha hızlı ve başarılı sonuç alınmasına neden olmuş olabilir. Küçük yaştaki çocukların en kritik sosyal-iletişim deneyimleri, birincil bakım verenleri ve aile üyeleri ile girdikleri etkileşimler sırasında oluşmakta ve aile-çocuk etkileşimleri, çocukların dil ve sosyal-iletişim becerileri kazanmalarını desteklemede kritik rol oynadığı düşünüldüğünde (McCollum ve Hemmeter, 1997; Wetherby ve Prizant, 2000) bu araştırma bulguları da bu inancı destekler nitelikte sonuçlanmıştır. Verilen eğitimin çocukların sosyal etkileşim becerilerine etkisinin sürüp sürmediğini belirlemek için, uygulama bittikten iki ay sonra toplanan izleme verileri sonucunda her üç katılımcı çocuğun sosyal etkileşim becerilerini artırarak koruduğu görülmüştür.

Sosyal etkileşimdeki sınırlılıklar OSB'nin erken göstergeleri arasında yer alsa da, sınırlı sosyal becerilerin ve gecikmiş sosyal gelişimin olası etkilerini iyileştirecek uygun müdahaleler genellikle sosyal etkileşimin belirli boyutlarına odaklanma eğilimi göstermektedir. Mahoney vd. (1999) oluşturulacak olan müdahale programlarının hem sosyal etkileşim becerilerini bütün olarak ele alması, hem de ailelerin dahil edilmesi yönündeki inanışını bu araştırmanın bulguları destekler niteliktedir. Çünkü aileleri birincil derecede dahil eden bir erken müdahale programı olan ETEÇOM Programı'nın tüm gelişim alanlarını ilerletmeye yönelik bütüncül bir program olması, bu gelişim alanları içerisinde iletişim ve sosyal duygusal alanlara yönelik stratejileri kapsamasından dolayı, OSB'li çocukların sosyal etkileşim becerilerini olumlu yönde desteklediği düşünülmektedir. Çünkü bu araştırmada ETEÇOM Programı ile hem sosyal etkileşimi destekleyen becerilere hem de sosyal etkileşim becerisinin bileşenlerini bir bütün halinde ele alarak incelenmiştir. Bunun sonucu olarak da, ETEÇOM Programı uygulanmadan önce çocukların sosyal etkileşim düzeyleri sınırlı iken, anneler eğitim aldıktan sonra çocukları 
ile daha nitelikli rutinler yaratmaya çalışıp, çocukları ile girdikleri etkileşimin kalitesini artırdıklarında OSB'li çocukların sosyal etkileşim becerilerinde artış olduğu bulgulanmıştır.

Doussard-Roosevelt Joe, Bazhenova, ve Porges (2003), yaptıkları bir araştırmada, 24 OSB'li okul öncesi dönem çocuğu ve 24 normal gelişim gösteren okul öncesi çocuk, anne-çocuk oyun oturumları ile karşılaştırılırken ayrıca 9 annenin OSB'li olan ve OSB'li olmayan çocuklarıyla oyun oturumları karşılaştırılmıştır. Bu araştırmada, bebekler ve yürüme çağındaki çocuklar için; günlük rutin ve aktivitelerde aile ile duyarlı bir etkileşim içerisinde olmanın, öğrenme ve gelişimin desteklenmesi için önemli firsatlar sunduğunu göstermiştir. Powell ve Dunlap, (2010)' in ifade ettikleri gibi çocuk gelişiminde aile etkisi oldukça kritiktir; aileler, bebeklerin ve yürüme çağındaki çocukların öğrenme süreçlerindeki en etkili ve kolaylaştırıcı etkenlerdir. $\mathrm{Bu}$ nedenle erken müdahale programları doğrudan çocuğa hizmet vermektense, ailelerin, çocuklarının gelişimini destekleyecek becerileri içerecek şekilde programlara odaklanmalıdır. Aile üzerindeki bu odaklanma, çocuğun anlamlı rutinler ve aktiviteler esnasında birden çok öğrenme firsatına sahip olmasını garanti altına alınacağı belirtilmektedir (Jung, 2003; McWilliam, 2012). Bu araştırmada da alanyazında yer alan bilgilerle utarlı olarak çocukların birincil bakım verenleri ile girdikleri etkileşimlerin kalitesi, aktivite ve rutinlere gösterdikleri katılımlar ile bu faaliyetlerdeki öğrenme becerilerini yakından etkilemekte ve dolayısıyla da, bir taraftan çocukların gelişimsel sonuçlarına etki ederken, diğer taraftan da anlamlı ve karşılıklı olarak faydalı etkileşimler yaratmakta olduğunu ortaya koymaktadır. Wilcox ve Shannon (1996), çocukların iletişim kurmak için sarf ettikleri çabalara yönelik yetişkinlerin takındıkları yanıtlayıcı davranış stillerinin, çocukların sosyal etkileşimlerinde ilerleme olma olasıllı̆ını artırdığını araştırmalarında bulgulamışlardır (aktaran Woods, Kashınath ve Goldstein, 2004). Yapılan bu araştırmada da annelerin etkileşim davranışlarında olumlu yönde artış ile birlikte çocukların sosyal etkileşimi başlatma, etkileşime yanıt verme ve etkileşimi sürdürme davranışlarında artışlar kaydedilmiştir.

Bu sonuçların, alan yazında ETEÇOM Programı'nın etkililiğine yönelik yapılmış araştırmalarla da paralellik gösterdiği ortaya çıkmıştır (örn., Karaaslan vd., 2011; Mahoney ve Perales, 2003; Toper, 2015). Ayrıca alanyazında OSB'li çocukların en sınırlı olduğu alanların başında gelen sosyal etkileşim becerilerine odaklanması, bu çalışmanın en ayırt edici özellikleri arasındadır. Araştırma bulguları, uygulayıcılara yönelik çıkarımlar sunmaktadır. İlk önce, küçük yaştaki yetersizlikten etkilenmiş çocuklara yönelik olarak önerilen aile-merkezli ve aile-yönlendirmeli uygulamalar, erken dönem OSB müdahalelerinde çok daha fazla rol almalıdırlar; çünkü, bu bulgular, böylesi yaklaşımlar için potansiyel etkililik göstermişlerdir. İkincisi, ebeveyn-çocuk 
ilişkisine dayalı bir müdahale oluşturmak, özellikle erken dönem OSB'li çocuklar açısından öncelik taşımalıdır. Üçüncüsü, OSB'li küçük yaş grubu çocuklara yönelik hizmetlerin, mevcut bulgular 1şı̆̆ında incelenmesi gerektiği yönündeki tavsiyeler, doğal aile ortamlarında gerçekleşen ebeveyn-çocuk etkileşimlerini baz almaktadır. Öte yandan bu araştırmada sınırlılık olarak sayılabilecek bazı noktalarda söz konusudur. Söz konusu sınırlılıklar; 1. Araştırma, yalnızca Ankara illerinde ikamet etmekte olan OSB tanısı almış üç çocuk ve anne ile yürütülmüştür. Dolayısıyla bu araştırmada ETEÇOM Programı'nın Türk çocukları ve anneleri üzerindeki etkisine ilişkin elde edilen sonuçların evrene genellemesi açısından araştırmanın tek denekli deneysel desenlerin getirdiği temel sınırlılık göz önüne alınmalıdır. 2. ETEÇOM Programı 16 temel davranışı ve 66 yanıtlayıcı etkileşim stratejisi içerirken bu araştırmada 15 temel davranışa, 40 yanıtlayıcı etkileşim stratejisine yer verilmiş olması dikkate alınmalıdır. 3 . Araştırmanın anne ile yürütülmüş olması da sınırlılıklar arasında yer almaktadır. 4. Araştırmada genelleme verilerinin alınmamış olması da sınırlılıklar arasında sayılabilir.

Araştırmadan elde edilen sonuçlar doğrultusunda ileride yapılacak uygulamalar ve araştırmalar için çeşitli öneriler bulunmaktadır.

1. Araştırmada amaçlanmadığı halde annelerle yapılan oturumlar sırasında evdeki diğer aile fertlerinin de öğrenilen stratejileri kullanmaya başladıkları ve bunun sonucu olarak da kardeşleri ve babaları ile de sosyal etkileşimlerinin arttığı yönünde bilgi alınmıştır. Bu nedenle ETEÇOM Programı'nın, tüm yetersizlik gruplarıyla ve özellikle OSB'li küçük çocukların annebabaları, kardeşleri ve yakın çevresindeki diğer kişiler tarafından, çocuğun içinde bulunduğu tüm ortamlarda kullanılması önerilebilir.

2. ETEÇOM Programının OSB'li çocukların sosyal etkileşim becerilerine etkisine yönelik olarak akran destekli uygulamalara yer verilerek de çalışılması önerilebilir.

\section{KAYNAKÇA}

American Psychiatric Association (2013). Diagnostic and statistical manual of mental disorders (5th Ed.). Washington, DC: Author.

Alvarez, A. (1999). Addressing the deficit: Developmentally informed psychotherapy with passive undrawn children. A. Alvarez, \& S. Reid (Eds.), Autism and Personality (s. 4961). New York: Routledge.

Baker, J., Messinger, D., Lyons, K. K., \& Gantz, C. J. (2010). A pilot study of maternal sensitivity in the context of emergent autism. Journal of Autism and Developmental Disorder, 40, 988-999. 
Baker, J. K., Fenning, R. M., Crnic, K. A., vd. (2007). Prediction of social skills in 6-year-old children with and without developmental delays: Contributions of earlyregulation and maternal scaffolding. American Journal on Mental Retardation, 112(5), 375-391.

Beckman, P., \& Lieber, J. (1994). The social strategy rating scale: An approach to evaluating social competencee. Journal of Early Intervention, 18, 1-11.

Bekman, S. (1998). Eşit firsat anne-çocuk eğitiminin değerlendirilmesi. İstanbul: Anne Çocuk Eğitim Vakfi.

Bierman, K., \& Wargo, J. (1995). Predicting the longitudinal course associated with aggressiverejected, aggressive (nonrejected), and rejected (nonagressive) status. Development and Psychopathology, 7, 669-682.

Billingsley, F. F., White, O. R., \& Munson, R. (1980). Procedural reliability: A rationale and an example. Behavioral Assessment, 2, 229-241.

Brookman-Frazee, L., Stahmer, A., Baker-Ericze'n, M. J., \& Tsai, K. (2006). Parenting interventions for children with autism spectrum and disruptive behavior

disorders: Opportunities for cross-fertilization. Clinical Child and Family Psychology Review, 9(3/4), 181-200.

Carter, A. S., Gillham, J. E. Sparrow, S. S., \& Volkmar, F. R. (1996). Adaptive behavior in autism. Mental Retardation, 5, 945-960.

Cassel, T. D., Messinger, D. S., Ibanez, L. V., Haltigan, J. D., Acosta, S. I., \& Buchman, A. C. (2007). Early Social and emotional communication in the infant siblings of children with autism spectrum disorders:An examination of the broad phenotype. Journal of $\quad$ Autism and Developmental Disorders, $\quad 37,122-132$.

Ceber-Bakkaloğlu, H., \& Sucuoğlu, B. (2000). Normal ve zihinsel engelli bebeklerde annebebek etkileşiminin karşılaştırılmalı olarak incelenmesi. Özel Ĕgitim Dergisi, 2 (4),

47-58.

Charlop, M. H., Dennis, B., Carpenter, M. H., \& Greenberg, A. L. (2010). Teaching socially expressive behaviors to children with autism through video modeling. Education \& Treatment of Children, 33(3), 371-393.

Clarizio, H. (1997). Conduct disorders: Developmental considerations. Psychology in the Schools, 34(3), 253- 265.

Craig-Unkefer, L. A., \& Kaiser, A. P. (2002). Improving the social communication skills of atrisk preschool children in a play context. Topics in Early Childhood Special

Education, 22(1), 3-13. 
Cotugno, A. J. (2009). Social competence and social skills training and intervention for children with autism spectrum disorders. Journal of Autism and Developmental Disorders, 39(9), 1268-1277.

Dawson, G., \& Galpert, L. (1990). Mothers' uses of imitative play for facilitating social responsiveness and toy play in young autistic children. Development and Psychopathology, 2, 151-162.

Diken, Ö. (2009). Ebeveyn davranışını değerlendirme ölçeği ve çocuk davranışını değerlendirme ölçeğinin geçerlik ve güvenirlik çalışmaları. Doktora Tezi, Anadolu

Üniversitesi Sağlık Bilimleri Enstitüsü Dil ve Konuşma Terapistliği Anabilim Dal1, $\quad$ Eskişehir.

Diken, İ. H. (2012). An exploration of interactional behaviors of Turkish mothers and their children with special needs: Implications for early intervention practices. Science, 37(163), 283-296.

Diken, İ. H. (2013). Gelişim geriliği/yetersizliği olan çocuklar, aileleri, eğitimcileri ve uzmanlarına yönelik etkileşim temelli erken çocuklukta müdahale programı: ETEÇOM hakkında ve ETEÇOM Formları 1, ETEÇOM Statejileri 2, ETEÇOM Bilgi Notları 3.

Orjinal ad:Autism and developmental delays in young children: The responsive teaching cirriculum for parents and professionals Gerald Mahoney \&James MacDonald (2007), Pro-Ed.:USA

Diken, İ. H., Ardıç, A., \& Diken, Ö. (2011). GOBDÖ-2-TV Gilliam Otistik Bozuklukları Derecelendirme Ölçeği 2 Türkçe Versiyonu. Ankara: Maya

Doussard-Roosevelt, J. A., Joe, C. M., Bazhenova, O., \& Porges, S.W. (2003). Mother-child interaction in autistic and nonautistic children: Characteristics of maternal approach

behaviors and child social responses. Development and Psychopathology, 15, 277-295.

Frith ,U., \& Frith,C. (2001). The biological basis of social interaction. Current Directions in Psychological Science, 10 (5),151-155.

Gast, D. L., \& Ledford, J. (2010). Multiple baseline and multiple-probe designs. D. L. Gast (Eds.), Single subject research methodology in behavioral sciences. New York: Routledge Publishers.

Greenspan, S. I., \& Wieder, S. (1999). A functional developmental approach to autism spectrum disorders. Journal of the Association for Persons with Severe Handicaps, 24(3), 147161.

Hobson, R. P. (1993). The emotional origins of interpersonal understanding. Philosophical Psychology, 6, 227- 249. 
Ingersoll, B., \& Gergans, S. (2007). The effect of a parent-implemented imitation intervention on spontaneous imitation skills in young children with autism. Research in Developmental Disabilities, 28 (2), 163-175.

Jung, L. A. (2003). More is better: Maximizing natural learning opportunities. Young Exceptional Children, 6(3), 21-26.

Kaiser, A. P., \& Hemmeter, M. L. (1996). The effects of teaching parents to use responsive interaction strategies. Topic in Early Childhood Special Education, 16(3), 375.

Kaiser, A. P., \& Hancock, T. B. (2003). Teaching parents' new skills to support their young children's development. Teaching Parents New, 16(1), 9-21.

Karaaslan, Ö. (2010). Etkileşime dayalı erken ĕ̆itim programı'nın (edep) gelişimsel yetersizliğe sahip çocuklar ve anneleri üzerindeki etkililiği. Doktora Tezi,

Anadolu Üniversitesi Eğitim Bilimleri Enstütüsü, Eskişehir.

Karaaslan, Ö., Diken, İ. H., \& Mahoney, G. (2011). The effectiveness of the responsive teaching parent-mediated developmental intervention programme in turkey: A pilot study. International Journal of Disability, Development and Education, 58(4), 359-

372.

Kırcaali-İftar, G., ve Tekin, E. (1997). Tek Denekli AraĢtırma Yöntemleri. 1. Baskı Ankara: Türk Psikologlar Derneği.

Kim, J., \& Mahoney, G. (2004). The effects of mother's style of interaction on children's engagement:Implications for using responsive intervention with parents. Topics in Early Childhood Special Education, 24 (1), 31-38.

Kim, J., \& Mahoney, G. (2005). The effects of relationship focused intervention on Korean parents and their young children with disabilities. Research in Developmental

Disabilities, 26 (2), 101-201.

Klein, P. S. (2003). A mediational approach to early intervention: Israel. S. L. Odom, M. J. Hanson, J. A. Blackman, \& S. Kaul (Eds.), Early intervention practices around the world (s. 69-89). Baltimore: Paul H. Brookes.

Koyuncu, M. (2009). Karşılıklı yoğunlaştırılmış etkileşim yönteminin otizmli çocuklarda iletişim becerilerinin gelişimine etkisinin değerlendirilmesi. Yüksek Lisans

Tezi, Selçuk Üniversitesi Sosyal Bilimler Enstitüsü, Konya.

Layton, T. L., \& Watson, L. R. (1995). Enhancing communication in nonverbal children with autism. K. A. Quill (Eds.), Teaching children with autism: Strategies to enhance communication and socialization (s. 73-102). New York: Delmar Publishers. 
Lee, S., Odom, S. L., \& Loftin, R. (2007). Social engagement with peers and stereotypic behavior of children with autism. Journal of Positive Behavior Interventions, 9, 67-79.

Mahoney, G., Kaiser, A. P., \& Girolametto, L. E. (1999). Parent education in early intervention: A call for a renewed focus. Topics in Early Childhood Special

Education, 19(3), 131-140.

Mahoney, G., \& Perales, F. (2003). Using relationship-focused intervention to enhance the social- emotionational functioning of young children with autism spectrum disorders. Topic in Early Childhood Special Education, 23,77-89.

Mahoney, G., \& Perales, F. M. (2005). Relationship-focused early intervention with children with pervasive developmental disorders and other disabilities: A comparative

study. Developmental and Behavioral Pediatrics, 26(2), 77-85.

Mahoney, G., \& Perales, F. (2008). Early intervention:How relationship focused intervention promotes developmental learning. Down Syndrome Research and Practice, 13

(3), 47-53.

Mahoney, G., \& MacDonald, J. (2007) Autism and developmental delays in young children:The Responsive Teaching curriculum for parents and professionals. Austin, TX: PRO-ED.

McCollum, J. A., \& Hemmeter, M. L. (1997). Parent-child interaction intervention whenchildren have disabilities. M. J. Guralnick (Eds.), The effectiveness of early intervention (s. 549-576). Baltimore, MD: Brookes.

McConachie, H., \& Diggle, T. (2007). Parent implemented early intervention for young children with autism spectrum disorder: A systematic review. Journal of Evaluation

in Clinical Practice, 13, 120-129.

McConnell, S. R. (2002). Interventions to facilitate social interaction for young children with autism: Review of available research and recommendations for educational intervention and future research. Journal of Autism and Developmental Disorders, 32(5), 351-372.

McWilliam, R. A. (2012). Implementing and preparing for home visits. Topics in Early Childhood Special Education, 31, 224-231.

Mundy, P., Sigman, M., \& Kasari, C. (1990). A longitudinal study of joint attention and language development in autistic children. Journal of Autism and Developmental Disorders, 20, 115-128.

Mundy, P., \& Newell, L. (2007). Attention, joint attention and social cognition. Current Directions in Psychological Science, 16, 269-274. 
Özdemir, S. (2007). A paradıgm shıft in early interventıon services: from child centeredness to famıly centeredness. Ankara Üniversitesi Dil ve Tarih-Coğrafya Fakültesi

Dergisi, 47(2), 13-25.

Özdemir, S. (2008). Family centered early intervention services. E-Journal of New World Sciences Academy, 3 (2),321-331.

Özdemir, S., \& Gürel, Ö. (2010, Ekim). Erken mudahale alaninda son 40 yil: Değişen yaklaşımlara genel bir bakış. 20. Ulusal Ozel Egitim Kongresi'nde sunulmuş

bildiri, Gaziantep.

Powell, D., \& Dunlap, G. (2010). Family-focused interventions for promoting social-emotional development in infants and toddlers with or at risk for disabilities.

Tampa, Florida: University of South Florida.

Prizant, B. B., Wetherby, A. M., \& Rydell, P. J. (2000). Communication intervention issues for children with autism spectrum disorders. A. M. Wetherby, \& B. M. Prizant

(Eds.), Autism spectrum disorders: A transactional developmental perspective (s.193-224). Baltimore: Paul H.Brookes.

Rogers, S. J. (2000). Interventions that facilitate socialization in children with autism. Journal of Autism and Developmental Disorders, 30(5), 399-409.

Schertz, H. H., \& Odom, S. L. (2007). Promoting joint attention in toddlers with autism: A parent-mediated developmental model. Journal of Autism and Developmental Disorders, 37,1562-1575.

Sigman, M., \& Ruskin, E. (1999). Continuity and change in the social competence of children with autism, Down syndrome, and developmental delays. Monographs of the

Society for Research in Child Development, 64, 1-114.

Simpson, R. L., Myles, B. S., Sasso, G. M., \& Kamps, D. M. (1997). Social skills for students with autism (2nd $\quad$ ed.). Reston, VA: Council for Exceptional Children.

Solomon, R., Necheles, J., Ferch, C., \& Bruckman, D. (2007). Pilot study of a parent training program for young children with autism: The play project home consultation program. Autism, 11(3), 205-224.

Stone, W., Ousley, O., Yoder, P., Hogan, K., \& Hepburn, S. (1997). Nonverbal communication in 2 and 3 year old children with autism. Journal of Autism and Developmental Disorders, 2, 677-696.

Tawney, W. J., \& Gast, L. D. (1984). Single subject research in special education. Columbus: Bell and Howell Company. 
Temel, F., Ersoy, Ö., Avc1, N., \& Turla, A. (2004). Gazi erken çocukluk gelişimi değerlendirme aracı "GEÇDA". Ankara: Rekmay.

Toper-Korkmaz, Ö. (2015). Eve dayalı olarak gerçekleştirilen etkileşim temelli erken çocuklukta müdahale programının otizm spektrum bozukluğu tanılı çocuklar ve anneleri üzerindeki etkililiği. Yayınlanmamış Doktora Tezi, Anadolu

Üniversitesi Eğitim Bilimleri Enstitüsü, Eskişehir.

Wetherby, A. M., Prizant, B. M., \& Hutchinson, T. (1998). Communicative, social-affective, and symbolic profiles of young children with autism and pervasive developmental disorder. American Journal of Speech- $\quad$ Language Pathology, 7, 79-91.

Wetherby, A. M., \& Prizant, B. M. (2000). Autism spectrum disorders: A transactional developmental perspective. Baltimore, MD: Brookes.

Woods, J., Kashınath, S., \& Goldstein, H. (2004). Effects of embedding caregiver-1mplementad teaching strategies in daily routines on children's communication outcomes. Fournal of Early Intervention, 26(3),175-193. 